Studies in Science and Technology Education

No. 99

\title{
Tekniklärares attityder till teknikämnet och teknikundervisningen
}

Charlotta Nordlöf

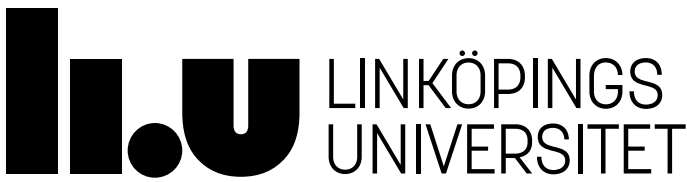

Institutionen för samhälls- och välfärdsstudier TekNaD, Teknik, naturvetenskap och didaktik Utbildningsvetenskap

Linköpings universitet, SE-601 74 Norrköping Norrköping 2018 
TekNaD, Teknik, naturvetenskap och didaktik, är en forskningsmiljö vid Institutionen för samhälls- och välfärdsstudier, Campus Norrköping, Linköpings universitet. TekNaD omfattar ett trettiotal seniora forskare, postdoktorer och doktorander i naturvetenskapernas och teknikens didaktik, och forskningen fokuserar exempelvis skolämnets historia; begreppslig förståelse; undervisningens innehåll; analogier, modeller och representationer; multimodalitet; lärares och elevers attityder; genusfrågor och bedömning. TekNaD ger ut doktors- och licentiandavhandlingar i serien Studies in Science and Technology Education.

(C) Charlotta Nordlöf, 2018

Tryckt i Sverige av LiU-Tryck, Linköping, 2018

Studies in Science and Technology education, No. 99

ISSN 1652-5051

ISBN 978-91-7685-328-3 
Tekniklärares attityder till teknikämnet och teknikundervisningen

Av

\title{
Charlotta Nordlöf
}

\author{
Januari 2018 \\ ISBN 978-91-7685-328-3 \\ Studies in Science and Technology Education \\ No. 99 \\ ISSN $1652-5051$
}

\begin{abstract}
SAMMANFATTNING
Skolforskning i allmänhet visar på att läraren är viktig, läraren är faktiskt en av de viktigaste faktorerna för elevernas framgång. Läraren är betydelsefull både när det gäller elevernas prestationer och deras attityder. Från tidigare attitydforskning vet vi att lärarens attityder har betydelse för undervisningen, men även för lärarens eget tankesätt. När det kommer till området teknikundervisning behöver lärarnas attityder undersökas och utforskas mer, vilket denna licentiatuppsats, bestående av två delstudier, bidrar till. Den övergripande forskningsfrågan är; Vad har svenska tekniklärare i grundskolan för attityder till teknikämnet och teknikundervisningen? Tekniklärarnas attityder har undersökts med både kvantitativa och kvalitativa metoder. Den första studien baseras på en enkätundersökning med 1153 tekniklärare i Sverige. Till att börja med identifierades fyra dimensioner av attityd i materialet; Teknikundervisning är viktigt, Förutsättningarna för teknikundervisning är goda, Kursplanen är i fokus för teknikundervisningen och Läraren har intresse, kunskap och självförtroende. Vidare så fanns tre kluster av lärare, Positiva, Negativa och Blandade, vilka baserades på lärarnas attityd till teknikämnet och teknikundervisning. Därefter testades olika variabler som prediktorer för klustertillhörighet, och att ha tekniklärarutbildning visade sig vara den mest betydelsefulla prediktorn. Licentiatuppsatsens andra studie är kvalitativ och bygger på intervjuer med 10 svenska tekniklärare. I den delstudien studeras en specifik del av attityder till teknikundervisning, nämligen lärarnas upplevda kontroll, som består av två komponenter; upplevd självförmåga (self-efficacy) och kontextberoende. Studien resulterade i tre underkategorier av upplevd självförmåga (self-efficacy). Dessa var Erfarenhet, utbildning och intresse, Ämneskunskap och Förberedelse. Vidare så
\end{abstract}


utvecklades fyra underkategorier av kontextberoende; Stöd av kollegor, Kursplan, Resurser och Status. Lärare har olika attityder till olika delar av teknikundervisningen, men generellt sett så har lärare med tekniklärarutbildning fördelar vad gäller attityd. Vidare så pekar resultatet på att kontextuella faktorer både kan begränsa och utveckla teknikundervisningen.

Att avsätta tid på olika sätt: genom tid för teknikundervisning, tid för tekniklärare att mötas och tid för utbildning av tekniklärare, visar sig vara möjliga vägar för att komma framåt och att förbättra tekniklärares attityder till teknikundervisning.

Keywords: teknikdidaktik, teknikundervisning, teknik, attityder, tekniklärare, self-efficacy, kontextberoende

Institutionen för samhälls- och välfärdsstudier TekNaD, Teknik, naturvetenskap och didaktik Utbildningsvetenskap Linköpings universitet SE-601 74 Norrköping, Sverige 
Swedish technology teachers' attitudes to the technology subject and to technology teaching.

By

\title{
Charlotta Nordlöf
}

\author{
January 2018 \\ ISBN 978-91-7685-328-3 \\ Studies in Science and Technology Education
}

No. 99

ISSN 1652-5051

\begin{abstract}
Teachers are important for students' achievement and students' attitudes in education in general; actually, the teacher is seen as one of the most important factors for student achievement. The teacher is important, for both the students' achievements and mind-sets. Attitudes matters in teaching and education, which is known from previous attitude research. In technology education, teachers' attitudes to technology education needs to be further investigated, and that is where this licentiate thesis, based on two studies, is contributing. The main research question was; What are Swedish technology teachers' attitudes to the technology subject and to technology teaching? In this licentiate thesis, technology teachers' attitudes were investigated by mixed methods, in two studies. The first study was based on quantitative research and an inquiry based on 1153 technology teachers in Sweden. The second study is qualitative and is based on ten interviews with Swedish technology teachers. In the first study four dimensions of attitude were found in the material; Technology education is important, Conditions are favourable for technology education, Curriculum is in focus in technology education and Confidence, interest and knowledge of the teacher is high. Further, three teacher clusters were identified, Positive, Negative and Mixed, based on teachers' attitudes towards technology education. Predictors for cluster belonging were identified, and for a positive attitude, education in technology was identified to be the most influential predictor. In the second study, teachers' perceived control, as a part of attitude, was studied in particular. Perceived control consist of two attitude components: self-efficacy and context dependency. Three sub-themes of self-efficacy were found; Experience, education and interest, Subject knowledge, and Preparation. Further, four sub-
\end{abstract}


themes of context dependency were found; Collegial support, Syllabus, Resources and Status. Teachers in this study have different attitudes to different parts of technology education, but teachers educated in technology generally seem to have advantages, when it comes to attitudes. The results further tells that contextual factors both can limit and boost technology education.

Time for teaching technology, time for technology teachers to meet and time for education of technology teachers, seems to be a key to how to find ways forward and how to improve teachers' attitudes towards technology teaching.

Keywords: technology education, attitudes, technology teachers, selfefficacy, context dependency

Department of Social and Welfare Studies, TESER, Technology and Science Education Research

The Faculty of Educational Sciences

Linköping University

SE-601 74 Norrköping, Sweden 


\section{Förord}

Norrköpings kommun och Linköpings universitet har gett mig en unik möjlighet att få gå en forskarutbildning! Mina år som licentiand har varit ett resultat av ett projekt i samarbete mellan universitet och kommunen, finansierat av Norrköpings fond för forskning och utveckling. Jag är tacksam för denna möjlighet och är nu glad och stolt över att snart kunna avsluta projektet genom att lägga fram min licentiatuppsats.

Det var nära att jag helt missade denna möjlighet, jag klickade mig fram på intranätet för att skicka in en ansökan om att bli förstelärare, och på raden under kunde jag läsa "Ämnesutvecklare och licentiand i teknik", vilket väckte min nyfikenhet. Jag skickade in min ansökan om förstelärartjänst, men var såklart tvungen att få veta mer om den andra tjänsten också. Sen gick det fort. Det var bara någon dag kvar till midsommar, och ansökan skulle vara inne efter helgen. Jag fick sätta fart och fick tillslut iväg ett brev inom utsatt tid. Och på den vägen är det..! Nu kan jag se tillbaka på fyra innehållsrika och utvecklande år, som har innehållit utmaningar, lärdomar och prövningar, men också progression, förkovran och glädje.

Det har varit en omställning att gå från att vara erfaren och rutinerad lärare på en arbetsplats jag kände väl, till att vara nybörjare och novis i en akademisk värld som jag inte visste speciellt mycket om innan. Jag kan faktiskt tänka att det var tur att jag inte visste vad jag gav mig in på, för då hade jag nog inte vågat söka. Jag känner mig fortfarande inte som en akademiker, men jag är inte heller läraren jag var för fyra år sedan. Nu har jag utvecklats inom ett spännande område i gränslandet mellan universitet, kommun och skola.

Jag har ju haft lyckan att kunna kombinera mina forskarstudier med arbete både i Norrköpings kommun och på CETIS, Centrum för tekniken i skolan, vid Linköpings universitet. Jag har i min tredelade tjänst arbetat med teknikämnet i skolan på alla möjliga sätt, förutom med just undervisning av elever. Det har varit så givande och roligt! $\mathrm{Nu}$ ser jag fram emot nya utmaningar med teknikämnet som gemensam nämnare också i fortsättningen.

Mina handledare har varit ett stöd och en resurs genom åren. Ni har handlett och guidat mig mot målet, och det har varit så givande att få jobba tillsammans med er. Jag har lärt mig mycket. Ett varmt och hjärtligt tack till er båda, Jonas Hallström (huvudhandledare) och Gunnar Höst (biträdande handledare). Jag har inför varje handledningstillfälle sett fram emot att träffa er! Tänk vilken möjlighet det har varit att ha haft tid avsatt i kalendern för att prata om mitt arbete och 
hur det kan bli bättre, och att två professionella personer har tagit sig tid att läsa och engagera sig i det jag gjort. Det kommer jag att sakna.

Det är så många fler jag vill tacka för dessa fyra år. Till att börja med Norrköpings kommun och Linköpings universitet som genom samverkan skapade denna möjlighet. Tack till Thomas Ginner, Jonas Hallström och Bitte Sundin som drog igång licentiandprojektet som sponsrades av Norrköpings fond för forskning och utveckling. Jag vill också säga tack till Kajsa Andersson Lundblad, min chef, som stöttat, uppmuntrat och ser möjligheter med att anställa mig som lektor i Norrköpings kommun, efter detta projekts avslutande. Nu ser jag fram emot att få jobba tillsammans med alla på FoU-avdelningen! På FoUavdelningen finns många duktiga och kompetenta människor. Några jag speciellt vill nämna som hjälpt mig framåt är Sofie Lindén, utbildningsdirektör och Annika Karlsson, strateg. Tack för att ni stöttat mig och gjort mig till en del av gänget trots att jag haft min arbetsplats i andra lokaler. Det är ibland svårt att veta vem man ska vända sig till och hur man ska gå till väga med olika saker när man inte så ofta är på plats på en arbetsplats - men det har oftast gått bra, och det måste jag tacka Sara Westling för! Du har hjälpt mig så många gånger med praktiska saker, du vet vem man ska prata med och du tar dig alltid tid att hjälpa till. Sen har jag också haft förmånen att få jobba med dig i olika uppgifter, det har varit utvecklande och det ska bli roligt att få fortsätta samarbeta.

Bosse Larsson och jag har följts åt genom licentiandåren, och det har varit fint att vara två i samma situation. Du började lite innan mig och slutade också före mig, och jag tackar för goda råd. Vi delade också arbetsrum den första tiden, tillsammans med Johan Svenningsson, Patrick Schooner och Alma Jahic Pettersson. Efter ett tag flyttade också Johan Boström och Johanna Frejd in. Tack ska ni ha för många roliga stunder och givande samtal. Och tack för samarbeten som fortsatt efter tiden i doktorandrummet. Johan och Patrick, det har varit så bra att kunna diskutera och ställa frågor till er om attityder, statistik, enkätutformning och annat. Nere på plan 1 har jag också bott granne med Magnus Jansson, och vi har kunnat hjälpas åt då vi kommit ungefär lika långt tidsmässigt med våra lic. uppsatser.

TekNaD - ingen nämnd, ingen glömd - har varit ett stöd genom mina år som licentiand, jag tänker speciellt på alla seminarier som genomförts och då speciellt tack till alla som engagerat sig i mina texter när det har varit jag som har lagt fram. Men, en person jag speciellt vill tacka är Anna Eriksson som alltid är hjälpsam och kan lösa det mesta. Jag har också haft förmånen att läsa många intressanta och spännande kurser, ibland svåra, men alltid givande. Det är många som har undervisat och som har delat med sig av erfarenheter, och er vill jag tacka. På 
mitt 60\% seminarium fick jag återkoppling och kommentarer från Erik Mellander, Eva Björkholm och Konrad Schönborn - tack för ert engagemang!

En del av min tid har jag arbetat på CETIS - Centrum för tekniken i skolan. Arbetskamraterna där har också varit ett stöd och en glädje för mig. Det har passat mig bra att inte forska på heltid utan att istället kunna blanda olika arbetsuppgifter. Så tack Classe, Katarina, Lena och resten av CETIS-gänget för glada stunder!

Jag vill också tacka CETIS, Teknikföretagen och Demoskop för att jag fick använda det material som ni samlade in genom ett enkätutskick till tekniklärare i Sverige 2012. Hade det inte funnits verksamma tekniklärare som gett av sin tid och bidragit med sina erfarenheter hade det ju inte blivit någonting alls av detta, tack för att ni tog er tid till att svara på enkäter och delta i intervjuer! Och tack till alla er därute som ställer upp när ni får frågan om att delta i någon forskningsstudie. Det är viktigt.

Livet består inte bara av arbete. Hemma har jag haft fullt stöd och förståelse för att forskarstudier kan engagera och spilla över på fritiden. Fredrik - tack för att du tror på mig och alltid uppmuntrat mig till att göra det jag trivs med. Mina söner har nog mest tyckt att det varit svårt att få grepp om vad deras mamma jobbar med, men jag ser fram emot att kunna visa dem den här boken. Jag vill också tacka mina föräldrar som ryckt in när barnen varit sjuka och hjälpt till på lov och studiedagar. Likaså mina svärföräldrar som kommit till Norrköping när fritids varit stängt eller när vi behövt jobba på lovdagar.

För mig har det varit viktigt att innehållet i licentiatuppsatsen, speciellt i kappan, ska vara lättbegripligt, även för läsare som inte jobbar i akademien med teknikdidaktik. Tack till er som hjälpt till att läsa en del av texten. Det är dels mina gamla kollegor frăn Ebersteinska gymnasiet Lena Rydström, Ewa Gynnhammar, Elsa Maria Lindqvist, Lizmari Svensgård och Matilda Scheibel Sahlin och dels mina anhöriga Stig Lind och Fredrik Nordlöf.

Norrköping i januari 2018

Charlotta Nordlöf 


\section{Ingående artiklar}

1. Nordlöf, C., Höst, G. E., \& Hallström, J. (2017). Swedish technology teachers' attitudes to their subject and its teaching. Research in Science \& Technological Education, 35(2), 195-214. doi:10.1080/02635143.2017.1295368

2. Nordlöf, C., Hallström, J., \& Höst, G. E. (2017). Self-efficacy or context dependency?: Exploring teachers' perceptions of and attitudes towards technology education. International Journal of Technology and Design Education, 1-19.

De publicerade artiklarna har tryckts med tillåtelse från respektive upphovsrättsinnehavare.

Published articles have been reprinted with permission of the respective copyright owners. 


\section{Innehållsförteckning}

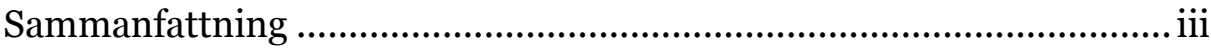

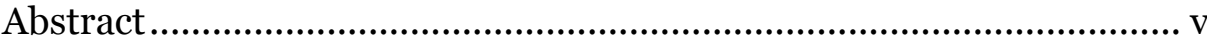

Förord............................................................................. vii

Ingående artiklar .......................................................... xi

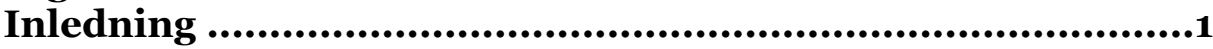

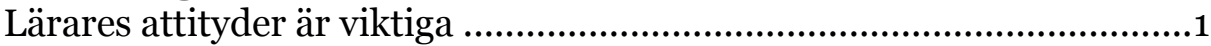

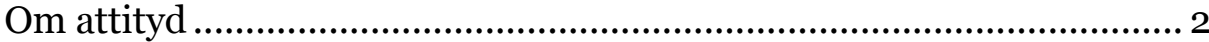

Syfte och frågeställningar ..................................................5 5

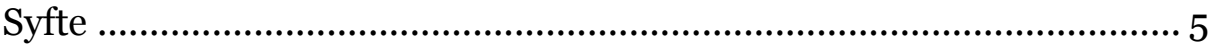

Frågeställningar .............................................................................. 5

Bakgrund - Teknikämnets framväxt och nutida utformning i

Sverige ........................................................................... 7

Teknikämnets framväxt ............................................................................ 7

Teknikämnet blir obligatoriskt - Lgr 8o.............................. 7

Teknik som eget kunskapsområde - Lpo 94 ........................... 8

Centralt innehåll och förmågor i teknik - Lgr 11 .................... 9

Nutidens teknikämne och teknikundervisning ..................................... 10

Lågt antal utbildade lärare som undervisar .......................... 10

Lärarlegitimationens införande 2011 ....................................... 11

Skolinspektionens granskning ................................................. 12

Olika teknikundervisning i olika klassrum .............................. 13

Teori och forskningsläge ................................................15

En modell av tekniklärares attityder ..................................................15

Tidigare forskning om lärares attityder till teknik och teknikundervisning ................................................................................17

Lärarstudenters attityder ...................................................... 17

Lärares attityder - följder för eleverna .................................. 18

Lärares attityder - Exemplet Nya Zeland................................. 19

Lärares attityder - kontextuella faktorer .............................. 20

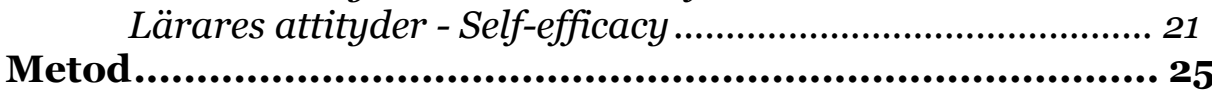

Metod i artikel 1 ................................................................................... 25

Deltagare och datainsamling ............................................... 25

Analysmetoder ........................................................................ 26

Metod i artikel 2 ......................................................................................31

Urval, deltagare och datainsamling ...................................... 31

Analysmetoder....................................................................... 32

Metoddiskussion - validitet, reliabilitet och etiska överväganden ....... 33

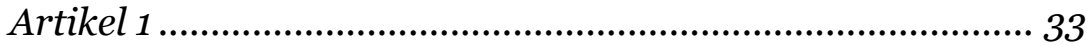

Artikel 2.......................................................................... 34

Forskningsetik ...................................................................... 34 
Om studierna och deras resultat ....................................... 37

Artikel 1: Tekniklärares attityder till sitt ämne och dess undervisning 37

Delresultat 1-fyra aspekter av attityd till teknikämnet och teknikundervisning ................................................................... 37

Delresultat 2 - tre lärargrupper .............................................. 38

Delresultat 3 - att förutsäga lärares attityd .......................... 40

Artikel 2: upplevd självförmåga och kontextberoende i teknikundervisningen ...................................................................42

Resultat ............................................................................ 43

Diskussion ...............................................................49

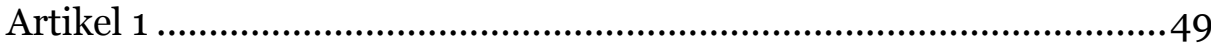

Artikel 2................................................................................ 52

Self-efficacy ........................................................................... 52

Context dependency ................................................................. 53

Övergripande slutsatser och implikationer .......................................... 56

Implikationer för yrkesverksamheten .............................................. 57

Låt teknikundervisning få tid ................................................. 57

Låt tekniklärarna få tid att mötas ........................................... 58

Låt tekniklärarna få tid för utbildning och

kompetensutveckling ................................................................. 59

Referenser ................................................................... 61

Bilaga 1: Intervjuguide .................................................... 67

Bilaga 2: Informationstext, webbenkät ............................71 
Kapitel 1

\section{Inledning}

I: Tycker du att det är någon skillnad, att det är svårare eller lättare att undervisa i teknik än i dina andra ämnen? C: Ja,jag tycker att det är lite lättare för att det är närmre mina privata intressen, det har jag mer kunskap för, så därför blir det ju lättare för mig. Till viss del. Sen är det ju såklart svårare för vi har ju inga teknikböcker på skolan, det finns inte så jättemycket material i nån tekniksal...

Carl, tekniklärare år 7-9.

Lärarens attityd - som handlar om så mycket mer än om ämnet teknik är viktigt eller inte - har betydelse för undervisningen. Undervisning sker inte i tomma klassrum. Nej, där undervisning sker är rummen fyllda med elever och lärare, och där människor möts har företeelser som känslor, inställningar och värderingar en viktig roll. Citatet ovan ger exempel på hur olika aspekter av attityd påverkar undervisningen för läraren Carl. Inre faktorer (intresse och kunskap) och yttre faktorer (böcker och material) påverkar hur undervisningen i hans klassrum kommer att gestaltas.

Den röda tråden i den här licentiatuppsatsen är tekniklärares attityder - vad attityder i teknikundervisning kan vara och vilken betydelse attityder kan få. I vardagligt tal använder vi nog ofta begreppet inställning, men i denna text väljer jag att använda det mer vetenskapliga begreppet attityd.

\section{Lärares attityder är viktiga}

Lärarens kompetens, förmåga och engagemang är alltså de undervisningsrelaterade faktorer som i högst grad påverkar elevers resultat (Johansson, 2010, p. 7).

Det mest betydelsefulla villkoret för om en elev ska lyckas i skolan är läraren. Detta visar både svensk och internationell forskning enligt en sammanställning om framgång i undervisningen gjord av Skolinspektionen (Johansson, 2010). I denna studie är därmed utgångspunkten att läraren är viktig. Elevernas lärande är givetvis det mest centrala 
i hela utbildningsväsendet, men i denna studie är läraren i centrum. Jag väljer att studera teknikundervisning ur lärarnas perspektiv. Istället för att utgå från elevernas situation och då se läraren som en betydelsefull resurs för lärande, så ligger fokus i denna licentiatuppsats på läraren som individ - en person med känslor och tankar. Då blir attityd centralt. Lärare är människor, och människor påverkas av känslor och omgivningens förutsättningar. Genom att förstå begreppet attityd utifrån den modell som presenteras i nästa avsnitt, så framgår att attityd inte bara handlar om att tycka att teknikundervisning är roligt eller tråkigt. Attityd är både bredare och djupare än så. Att få en större förståelse för lärarens attityd innebär en inblick i lärares kognitiva uppfattningar (cognitive beliefs), känslomässiga förhållanden (affective states) och upplevda kontroll (perceived control), både inre och yttre.

Ett exempel på upplevd kontroll är självförmåga (self-efficacy). Hög upplevd självförmåga hos lärare visar sig ha goda följder, bland annat när det gäller elevers resultat, men också när det gäller lärarens egna tänkesätt; som villighet att föra in nya idéer i undervisningen och att stanna kvar i yrket (Tschannen-Moran, Hoy, \& Hoy, 1998). Läraren är alltså viktig för elevens framgång och måluppfyllelse.

I samband med införandet av teknikämnet på Nya Zeeland skev Jones and Carr (1992) om några aspekter av attityd till teknikundervisning. De beskrev hur lärarnas erfarenheter och föreställningar kom att påverka introduktionen av ämnet teknik. Lärares attityd har också studerats inom andra fält, där får naturvetenskapen vara ett exempel. Osborne, Simon, and Collins (2003) menar att god undervisning inbegriper en lärare som är hängiven sitt ämne. Vidare så har en lärare med positiv attityd till sitt ämne större möjlighet att inspirera och motivera sina elever (Osborne, Simon, \& Collins, 2003), något som inte minst blir intressant i samhällsdebatten om ungas yrkesval och vidare studier - vi hör ju ofta talas om att Sverige behöver fler människor som utbildar sig inom teknik och naturvetenskap. Att undersöka lärares attityder till sin undervisning är viktigt för att förstå hur undervisningen i naturvetenskap kan förbättras, menar Korur, Vargas, and Serrano (2016). Jag menar att samma sak gäller för teknikundervisningen.

\section{Om attityd}

Begreppet attityd är omfattande och mångsidigt och inte alltid enkelt att förstå. Det finns många, ja faktiskt hundratals, olika definitioner och förklaringar av vad attityd är och hur attityder är uppbyggda (Ajzen, 2005; Albarracín, Johnson, Zanna, \& Kumkale, 2005). Något som de flesta forskare och psykologer inom området ändå har enats om 
är att attityd till sin natur är värderande (för eller emot, bra eller dålig, trevlig eller otrevlig, o.s.v.) (Ajzen, 2001, 2005). Även om definitionen av begreppet attityd har varierat genom dess historia, är det just den värderande egenskapen som är tydligt återkommande (Albarracín et al., 2005). Inom forskningsområdet mäts attityder i skalor där individen ska värdera sig själv gentemot ett attitydobjekt (Ajzen, 2005). När man studerar attityder inkluderas både en persons värderingar i tillvaron i nutid och hans eller hennes minnesbilder, eller en kombination av båda två (Albarracín et al., 2005).

När det kommer till förklaringar av hur attityder är uppbyggda finns en modell som kan spåras till grekiska filosofer som är tredelad och inbegriper kognition, affekt och beteende (Ajzen, 2005; Breckler, 1984). Under 1960-talet utvecklade Rosenberg and Hovland (1960) en modell som fått stort genomslag i litteraturen. Den består på liknande sätt av indelningen i de tre komponenterna cognition (kognition), affect (känsla) och behaviour (beteende). Cognition innebär uppfattning, tilltro och föreställningar om det aktuella objektet, affect innebär känslan för objektet och behaviour innefattar hur en person reagerar och beter sig (Rosenberg \& Hovland, 1960). Modellen är hierarkisk, och de tre komponenterna är primära medan den övergripande attityden är sekundär (Ajzen, 2005). Genom åren har många olika försök gjorts för att bekräfta modellen, och resultaten har i de flesta fall också stöttat den tredelade modellen (Ajzen, 2005), men det finns också en uppfattning med bara en dimension av attityd, där attityd definieras som "a person's location on a dimension of affect or evaluation" (Dillon \& Kumar, 1985, p. 33). Det kan man till exempel se genom den diskussion som förts mellan olika forskare genom vetenskapliga artiklar kring frågan om huruvida attityd består av en eller flera dimensioner (t.ex. Bagozzi \& Burnkrant, 1985; Dillon \& Kumar, 1985). Vissa forskare anser därutöver att det är svårt skilja på kognition och affekt, och att dessa två komponenter därför inte bör särskiljas (Ajzen, 2005).

Om en tredelad modell förespråkas, ska likväl de tre komponenterna återspegla samma attityd, vilket innebär att de samtidigt som de representerar varsin attitydkomponent ändå ska korrelera så pass att de också visar på en övergripande attityd (Ajzen, 2005). Ett exempel på detta är en studie där ett test genomfördes genom att studenter fick svara på frågor om kognition, affekt och beteende gällande ormar, och resultatet validerade den tredelade modellen, samtidigt som korrelation mellan komponenterna påvisades (Breckler, 1984). Breckler (1984) menar att det egentligen inte går att mäta attityd övergripande eller generellt: 
...to say a researcher is measuring "attitude" is ambiguous, because it does not specify which of the three components is being measured. (Breckler, 1984, p. 1204)

I denna licentiatuppsats utgår jag ifrån att attityd är flerdimensionellt och består av flera komponenter, och precis som Ajzen (2001), anser jag att en person inte endast kan ha en attityd till ett objekt, och speciellt inte ett så komplext objekt som teknikundervisning. Dessutom så tas i denna licentiatuppsats stöd i en vidareutvecklad attitydmodell som har anpassats för lärares attityder till sitt ämne och undervisningen (van Aalderen-Smeets, Walma van der Molen, \& Asma, 2012). I denna modell beskrivs attityd med tre komponenter, men beteende är inte en attitydkomponent utan ett resultat av attityd. Attitydkomponenterna i den modellen är cognitive beliefs (kognitiva uppfattningar), affective states (känslomässiga förhållanden) och perceived control (upplevd kontroll). Modellen beskrivs i avsnittet teori. 
Kapitel 2

\section{Syfte och frågeställningar}

\section{Syfte}

Eftersom läraren är en viktig faktor för elevers framgång, så blir det både viktigt och intressant att få fördjupade kunskaper om lärarna. Det gäller speciellt lärare som undervisar i teknik, då teknikämnet i svensk skola har en relativt kort historia i och med att det infördes som obligatoriskt ämne i samband med Lgr 8o. Det innebär att det inom teknikdidaktiken finns många områden kvar att utforska.

Att få en djupare kunskap om lärares attityder till sin undervisning är viktigt för att få en klarare bild av teknikundervisningen. I undervisningssituationen möts människor, och undervisningen påverkas givetvis av lärarnas inställning och förhållningssätt till teknikämnet och till teknikundervisningen. En ökad förståelse för lärarna och undervisningen behövs för att skapa bättre förutsättningar för teknikundervisning. Syftet med denna licentiatuppsats är att bidra med nya och fördjupade kunskaper om tekniklärares attityder till sitt ämne och undervisningen. Det innebär en ökad förståelse för tekniklärarna genom att se teknikämnet och undervisningen ur lärarnas perspektiv. Licentiatuppsatsen består av två studier som tillsammans bidrar till en bred bild av tekniklärarnas upplevelser av teknikundervisning och vilka attityder som finns. Där till ges en djupare förståelse för en specifik aspekt av attityd, nämligen upplevd kontroll, hos lärarna.

\section{Frågeställningar}

De två studiernas gemensamma nämnare är tekniklärare och attityder, och båda delstudierna utgår från tekniklärarnas perspektiv. Licentiatuppsatsens övergripande frågeställning är Vad har svenska tekniklärare $i$ grundskolan för attityder till teknikämnet och teknikundervisningen?

I den första artikeln söks attityder till teknikämnet och teknikundervisning, hos tekniklärare i grundskolan, ur ett brett perspektiv, och dessutom eftersöks samband mellan attityd och olika bakgrundsvariabler. Frågorna är som följer: 
Kapitel 2

1. Vad har svenska tekniklärare för attityder till teknikämnet och undervisningen?

2. Vilka möjliga förklaringar finns till lärarnas olika attityder?

I den andra artikeln undersöks en smalare del av lärarnas attityder till teknikundervisning i svensk grundskola, med fokus på lärarnas upplevda kontroll, både inre kontroll (upplevd självförmåga) och yttre kontroll (kontextberoende).

1. Hur upplever lärarna self-efficacy (upplevd självförmåga) och context dependency (kontextberoende) i sin teknikundervisning? 


\section{Bakgrund - Teknikämnets framväxt och nutida utformning i Sverige}

Teknikämnet är det yngsta ämnet i svensk grundskola, och kanske också det mest föränderliga när det gäller innehåll. Den korta traditionen och den föränderliga karaktären motiverar att en redogörelse för ämnets historia är nödvändig. De lärare vars attityder studeras i denna licentiatuppsats befinner sig i en viss kontext. För att få en klarare bild av kontexten för teknikundervisning i Sverige, och för att skapa en bättre förståelse för ämnets karaktär och för vilka vändningar det har varit med om under sina knappa 40 år, följer här en tillbakablick.

\section{Teknikämnets framväxt}

\section{Teknikämnet blir obligatoriskt - Lgr 80}

Det var i samband med att läroplanen Lgr 80 introducerades i början av 1980-talet som teknik blev ett obligatoriskt ämne i grundskolan, som en del av de naturorienterande ämnena. Innan Lgr 80 var skolämnen med teknikinnehåll valbara. Det var under efterkrigstiden som ämnet uppstod. Det var en utveckling som låg i linje med samhällsutvecklingen i stort under den epoken, och under 6o-talet skapades en teknisk linje på grundskolan (Hultén, 2013). Anledningar till att teknikämnet sedan blev obligatoriskt i samband med Lgr 80 var att ge skolan en mer praktisk inriktning, att förändra skolans arbetssätt, öka intresset för tekniska och naturvetenskapliga studier och att ur ett jämställdhetsperspektiv ge alla samma förutsättningar till tekniskt kunnande (Elgström \& Riis, 1990). Det starkaste motivet var att öka intresset för naturvetenskapen och vidare högre studier inom detta område (Riis, 2013).

Vid införandet av teknik som obligatoriskt ämne ansågs det inte vara ett tillräckligt starkt skolämne för att stå för sig självt. Det var dock aldrig en självklarhet att placera det tillsammans med de naturorienterande (NO)-ämnena. Det andra alternativet till ämneskombination var slöjd och teknik, och då avsågs både trä- och textilslöjd (Elgström \& Riis, 1990). Det blev en dragkamp om teknikämnet mellan NO- och slöjd-ämnena, och i och med detta uppstod också en diskussion om teknikämnets karaktär. Resultatet av uppgörelsen blev att man skulle se teknik och NO-ämnena som en enhet, och teori och tillämpning skulle vara starkt förbundna. Tidigare hade teknikämnet haft en 
tydlig anknytning till slöjd- och yrkesämnen, vilken nu i och med kopplingen till NO, brutits (Lövheim, 2013). Den osäkerhet som rådde kring teknikämnets tillhörighet och identitet syntes sedan också i läroplanen, Lgr8o (Bjurulf, 2013). I läroplanen gavs ingen definition av begreppet teknik. Den slutliga placeringen av teknik tillsammans med NOämnena innebar en prägling av teknikämnet som ännu idag är påtaglig, trots att teknikämnet blev fristående 1994, eftersom ämnet fortfarande är starkt sammansvetsat med NO-ämnena, genom till exempel gemensam timplan.

Teknikämnets epok som obligatoriskt skolämne kan i jämförelse med andra länder ses som relativt lång, men i jämförelse med de svenska skolämnena är teknikämnet ett ungt sådant. Detta kan medföra svårigheter, då teknikläraren själva måhända inte har teknikundervisning i sin egen skolgång att förhålla sig till. Samtidigt kan ämnets korta tradition var en fördel, det innebär ju att en större öppenhet finns, och en mindre risk att hamna i gamla hjulspår (Bjurulf, 2013)

\section{Teknik som eget kunskapsområde - Lpo 94}

Inför framtagningen av Läroplanen för det obligatoriska skolväsendet, förskoleklassen och fritidshemmet Lpo 94 (Skolverket, 2006), hade synen på teknik som ämne förändrats. Av tidigare tradition hade teknikens funktion varit att stärka elevers kunskaper inom naturvetenskap och matematik (Hultén, 2013). Läroplanskommittén ansåg att teknik inte skulle anses vara tillämpad naturvetenskap, utan ett självständigt kunskapsområde. Det räckte inte längre med de två klassiska kunskapskulturerna naturvetenskap och humaniora, både teknik och samhällsvetenskap behövde finnas med som egna kunskapskulturer i den nya läroplanen (Lövheim, 2013). Carlgren (2013) menar att anledningen till att teknik blev ett eget ämne var att det i Lpo 94 generellt skulle vara enskilda ämnen istället för ämnesblock. Trots att teknik och NOämnena blev separata ämnen, kom de dock att i timplanen dela på 800 timmar i undervisningstid under hela grundskolan, utan några direktiv om fördelning av timmar mellan ämnena (Bjurulf, 2013).

Flera faktorer påverkade framskrivandet av den nya kursplanen i teknik. En faktor var att man under denna reform arbetade med en ny kunskapssyn som resulterade i de fyra F:en; Fakta, Förståelse, Färdighet och förtrogenhet, vilket givetvis påverkade hur man formulerade teknikämnets uppbyggnad. Ämnets utformning påverkades även av kunskapssynen hos de personer som satt med i kommittén som arbetade med kursplanen (Carlgren, 2013). Under arbetet med det nya ämnet teknik talade man om att kalla det för "Teknik och miljö", med tanke på miljöfrågornas betydelse för ämnet, och kopplingen till män- 
niska, samhälle och natur (Lövheim, 2013). Trots dessa diskussioner blev det självständiga skolämnet tillslut kort och gott "Teknik". Detta berodde på invändningar från biologiämnets företrädare vars ämne länge haft starka kopplingar till miljöfrågor, att regeringen förespråkade att miljöfrågor skulle genomsyra hela grundskolan, samt olika representanters åsikter om att miljö inte bara skulle vara kopplat till teknikundervisningen (Hallström, Hultén, \& Lövheim, 2014).

I Skolverkets kommentarer till kursplanerna i samband med en revidering 2000 framkom att ämnet teknik ansetts ha haft en otydlig identitet, och att man därför i kommentarmaterialet gett fler exempel än i andra ämnen, samt att både lärare och skolledare upplevt osäkerhet kring ämnets identitet (Skolverket, 2000). Att många lärare "fortfarande kände sig osäkra på vad teknikämnet egentligen representerade och vilken roll det skulle spela i undervisningen" (Skolverket, 2000, s. 54) visar att inställning och attityd hos lärare lyftes redan då.

\section{Centralt innehåll och förmågor i teknik - Lgr 11}

Den läroplan som infördes 2011, Läroplan för grundskolan, förskoleklassen och fritidshemmet 2011 (Lgr 11), är också den som gäller idag (Skolverket, 2011). Teknikämnet är fortfarande ett eget ämne, och det delar också alltjämt timplaneutrymme med NO-ämnena (80o timmar), vilket innebär att kopplingen mellan teknik och NO-ämnena finns kvar i praktiken. Teknikämnet beskrivs som tvärvetenskapligt och kursplanen har ett brett centralt innehåll, som anger kunskapsområden av olika karaktär som ämnet ska behandla, och förmågor som eleverna ska ges möjlighet att utveckla under hela skoltiden (Skolverket, 2011).

Teknikämnets fem förmågor gäller för hela grundskolan, årskurs 19. Dessa är formulerade enligt följande (Skolverket, 2011, s. 278):

Genom undervisningen i ämnet teknik ska eleverna sammanfattningsvis ges förutsättningar att utveckla sin förmåga att

- identifiera och analysera tekniska lösningar utifrån ändamålsenlighet och funktion,

- identifiera problem och behov som kan lösas med teknik och utarbeta förslag till lösningar,

- använda teknikområdets begrepp och uttrycksformer,

- värdera konsekvenser av olika teknikval för individ, samhälle och miljö, och

- analysera drivkrafter

Det centrala innehållet i Lgr11 består av tre områden:

- Tekniska lösningar 
- Arbetssätt för utveckling av tekniska lösningar

- Teknik människa samhälle och miljö

För varje område finns specifikt innehåll för årkurs 1-3, årskurs 46 samt årskurs 7-9. Detta bidrar till ämnets progression, som till exempel området teknik, människa, samhälle och miljö. I årskurs 1-3 handlar det om vardagliga föremål och om hur de är anpassade efter människans behov. I årskurs 4-6 behandlas vanliga tekniska system i hemmet och samhället. I årskurs 7-9 är det fokus på globala system och systemens fördelar, risker och sårbarhet (Skolverket, 2011).

\section{Nutidens teknikämne och teknikundervisning}

I detta avsnitt beskrivs nuläget för ämnet, för att ytterligare fördjupa bakgrunden och öka förståelsen för studiens båda artiklar.

\section{Lågt antal utbildade lärare som undervisar}

Teknikämnet är ett av ämnena i svensk grundskola med lägst andel behöriga lärare. Läsåret 2016/2017 hade 43,7 \% av alla tekniklärare i grundskolan legitimation och behörighet i ämnet (SiRiS, 2017). För att få något att jämföra med så var andelen lärare med legitimation och behörighet vid samma tidpunkt till exempel $67 \%$ i fysik, 78 \% i matematik och $55 \%$ i slöjd.

I en tidigare rapport från 2014, innan lärarlegitimationen hade slagit igenom, redovisar och jämför Skolverket andelen behöriga lärare i olika skolämnen och skolformer (Skolverket, 2014). Lägst andel behöriga tekniklärare fanns då i årskurs 1-3, där endast $27 \%$ av de som undervisar i ämnet var behöriga. Det kan jämföras med siffrorna från samma år för alla undervisande lärare i årskurs 1-3 där 60 \% var behöriga i de ämnen som de undervisade i. I årkurs 4-6 ökade behörigheten i teknik något till drygt 30 \% behöriga (jämfört med $52 \%$ behörighet i sina ämnen för alla undervisande lärare). I årskurs 7-9 var ca $45 \%$ av de undervisande lärarna behöriga i teknik (jämfört med 57 \% behörighet i sina ämnen för alla undervisande lärare). Se också mitt resonemang kring behörighet och legitimation nedan under rubriken "Lärarlegitimationens införande 2011".

Den låga andelen behöriga lärare är något som har följt teknikämnet genom åren. Under slutet av 70-talet, när teknik var ett tillvalsämne, saknade ca 60 \% av lärarna utbildning i teknik, även om de var behöriga lärare (Elgström \& Riis, 1990). Under 80-talet, när ämnet blivit en 
obligatorisk del av orienteringsämnena, saknade en stor del av lärarna, 20-25\%, helt en lärarutbildning. Hur många som saknade ämnesutbildning i teknik framgår inte. Tekniklärarna själva upplevde att "deras ämne behandlades sämre än andra ämnen" (Elgström \& Riis, 1990, s. 195). Andersson (1988) sammanfattade situationen vid införandet av teknikämnet både i Sverige och internationellt med att bristande lärarkompetens tillsammans med brist på material är villkor som försvårar. Inte heller på 90-talet skedde några större förändringar när det gäller tekniklärarnas utbildning. Centrum för tekniken i skolan (CETIS), som är ett nationellt resurscentrum med regeringsuppdrag att stimulera och utveckla teknikundervisning i svensk skola, tillsammans med lärare, förskollärare, lärarutbildare m.fl., gjorde 1998 en egen undersökning kallad "Hur står det till med Tekniken i skolan?" (CETIS, 1998). I denna undersökning samlades data in från 100 slumpvis utvalda skolor i Sverige. Resultaten visade att drygt 30 \% av lärarna hade teknik i sin grundutbildning och att drygt hälften hade maximalt en veckas fortbildning i ämnet.

\section{Lärarlegitimationens införande 2011}

Ett krav på legitimation för lärare infördes i skollagen 2011. Syftet med legitimationen var att öka kvaliteten i skolan och att höja statusen på läraryrket. För att fă undervisa, sätta betyg och kunna få en fast anställning krävs både behörighet och legitimation. För att kunna ansöka om lärarlegitimation, måste man först ha behörighet. En lärare blir behörig genom att ta examen på en behörighetsgivande lärarutbildning. Lärare kan ha behörighet för olika skolformer och olika ämnen, och olika kombinationer av dessa (Skolverket, 2016). Ett undantag för behörighet $\mathrm{i}$ ämnen är lång erfarenhet. En lärare som har lärarexamen och har lång erfarenhet (8 år eller mer de senaste 15 åren) av att undervisa i ett ämne kan bli behörig utifrån sin erfarenhet, detta undantag trädde i kraft i slutet av 2013 (Skolverket, 2013).

Undantaget innebar att fler lärare som undervisade i teknik kunde ansöka om legitimation för ämnet. De lärare som då kunde söka hade alltså inte någon utbildning $\mathrm{i}$ ämnet, men blev ändå legitimerade. Det kan vara en effekt av detta undantag som syns när man studerar andelen lärare med behörighet för ämnet teknik i Skolverkets databas SiRiS (SiRiS, 2017). Statistiken visar att antalet lärare i grundskolan med behörighet i teknik steg från ungefär 32 \% läsåret 2013/14 till 44 \% läsåret 2014/15. En möjlig tolkning är att detta undantag hade sådan effekt att andelen behöriga ökade med drygt 10 procentenheter, eftersom endast ett fătal studenter valde teknik på ämneslärarprogram- 
men, och att deltagandet i teknikkurser i Lärarlyftet varit lågt. Detta innebär att siffrorna ser bättre ut, men bakom siffrorna finns fortfarande ett antal lärare som inte har formell utbildning i ämnet.

\section{Skolinspektionens granskning}

I maj 2014 publicerade Skolinspektionen en kvalitetsgranskning, "Teknik - gör det osynliga synligt" (Skolinspektionen, 2014) av teknikundervisningen i 22 skolor i Sverige. Skolinspektionens definition av kvalitet är att arbetet sker i enlighet med de nationella styrdokumenten. Kvalitetsgranskningen blir också en rapport av hur teknikundervisningen såg ut vid den tidpunkten och dess resultat påvisar ett antal förbättringsområden.

Rapportens titel är en sammanfattning av inspektionens resultat. Teknikämnet hamnar på en undanskymd plats och kvaliteten behöver förbättras. I rapporten lyftes tre förbättringsområden.

1. Allt för sällan får elever möta en för dem relevant undervisning. Eleverna uppfattar undervisningen som varken intressant eller användbar. Undervisningen är inte heller tillräckligt utmanande och stimulerande. Elevernas, och särskilt flickornas, intresse för teknik sjunker, tvärt emot vad kursplanen i teknik förespråkar (Skolverket, 2011). Lärarna utgår inte från elevernas förkunskaper och eleverna får inte möjlighet att påverka undervisningen i den utsträckning som de borde.

2. Teknikämnets kännetecken blir otydliga och därmed blir också undervisningen det. Detta har flera orsaker: Både lärare med och utan behörighet att undervisa i teknik känner sig osäkra på kursplanen och de förhållningssätt och metoder som är utmärkande för teknikämnet. Ofta är det praktiska delar av undervisningen som tar överhand och bidrar till ett "oreflekterat görande". Det leder till att eleverna inte vet vad de ska lära sig av de praktiska momenten. Det är också vanligt förekommande med uppgifter som bara har en lösning, vilket inte stimulerar problemlösningsförmåga och kreativitet. Teknikämnet blir också otydligt då det ofta integreras med andra ämnen, och det blir speciellt otydligt tillsammans med de naturorienterande ämnena.

3. Skolorna kan inte erbjuda den undervisning som eleverna har rätt till. Det beror på brister i tid, kompetens, samverkan och materiella resurser. Granskningen visar att inte alla elever får de 
ca 200 timmar teknikundervisning som de ska garanteras. Och det som undervisas görs ofta på för låg nivå. På flera skolor har man sett att man utgått från det centrala innehållet för årskurs 4-6 när man undervisar i årkurs 7-9. Materiella resurser i form av läromedel, utrustning och material saknas på vissa skolor. Teknikämnet har inte tillräckligt stor betydelse som eget ämne, vilket visar sig i att det ofta nämns tillsammans med NOämnena och inte har betydelse för vidare studier på tekniska program på gymnasiet.

Vidare så föreslog Skolinspektionen fyra kritiska områden som skolor i Sverige bör ta hänsyn till för att utveckla intresset för teknik:

- Synliggör teknik för eleverna.

- Skapa mening och relevans, uppmärksamma särskilt flickorna.

- Utveckla lärarnas kompetens.

- Uppmärksamma teknikämnet - gör det osynliga synligt.

\section{Olika teknikundervisning i olika klassrum}

Skolinspektionens granskning (Skolinspektionen, 2014) visade att teknikundervisningen ser olika ut i olika klassrum. Samma sak förevisade också Sjöberg (2013, p. 49) då han beskrev och jämförde teknik med andra ämnen, på ett träffsäkert sätt:

I alla svenska grundskolor läser man ungefär samma fysikkurs, samma matematikkurs osv. I teknik är det däremot inte så. Där kan två skolor ha synnerligen olika innehåll i sina planeringar. Det som behandlas i den ena skolan behöver inte tas upp i den andra och vice versa. När elever och föräldrar märker detta, kan de dra den nedslående slutsatsen att stoffet inte är särskilt värdefullt - någon kan ju tydligen klara sig utan det.

Man skulle kunna sträcka sig ännu längre och säga att även lärare och skolledare kan uppfatta stoffet så, och att de olika vis som ämnet kan gestalta sig på gör det svårare att förstå för den som inte är insatt och påläst.

Att ämnet kan se olika ut är också något som påvisas i en avhandling av Bjurulf (2008) där hon har undersökt hur lärare uppfattar sko- 
lämnet teknik. Resultatet av studien visar att lärarens tekniksyn påverkar undervisningen. De fem lärarna i studien tolkade teknikämnet olika och ämnet beskrevs som att det tränar hantverksskicklighet, är en grogrund för blivande ingenjörer, är tillämpad naturvetenskap, stärker flickors självförtroende och är en nyckel till en fortsatt teknisk utveckling i samhället (Bjurulf, 2008, s. 115). Vidare så framkom tre faktorer som påverkar vilken undervisning eleverna får möta. Dessa handlar om (1) lärarens utbildning som påverkar dennes syn på ämnet och undervisningsinnehållet, (2) om man är i ett klassrum anpassat för teknik så erbjuds en annan typ av undervisning än om man är i en NO-sal och (3) om gruppstorleken, i en mindre undervisningsgrupp gavs mer praktiska uppgifter (Bjurulf, 2008). Vid studiens genomförande gällde Lpo 94 (Skolverket, 2008), men resultatet är inte knutet till läroplanen utan till lärarnas ämnesuppfattning. Synen på teknik ser också olika ut för olika lärare. Norström (2014) har undersökt detta och menar att det inte finns en enad tekniksyn vare sig bland lärare eller inom den teknikdidaktiska forskningen, och att detta innebär svårigheter när det kommer till teknikämnets innehåll. Dels när det gäller att särskilja teknikämnet från andra skolämnen, men också när det gäller att bedöma och utvärdera elevernas kunskaper. Lärarna har inte ett gemensamt språk som möjliggör för dem att diskutera teknisk kunskap, vilket skulle kunna innebära olika tolkningar av styrdokumenten, enligt Norström. Skolinspektionens kvalitetsgranskning (Skolinspektionen, 2014) bekräftar att teknikundervisningen i hög grad skiljer sig mellan olika skolor. 
Kapitel 4

\section{Teori och forskningsläge}

\section{En modell av tekniklärares attityder}

I licentiatuppsatsens båda studier har en specifik attitydmodell valts som teoretisk utgångspunkt. Modellen är utvecklad för att ge en förståelse för attityder, se figur 1, och utarbetades för att vara anpassad för lärares attityder till sin undervisning (van Aalderen-Smeets \& Walma van der Molen, 2013; van Aalderen-Smeets et al., 2012). Modellen har använts i andra attitydstudier, som till exempel Korur et al. (2016).

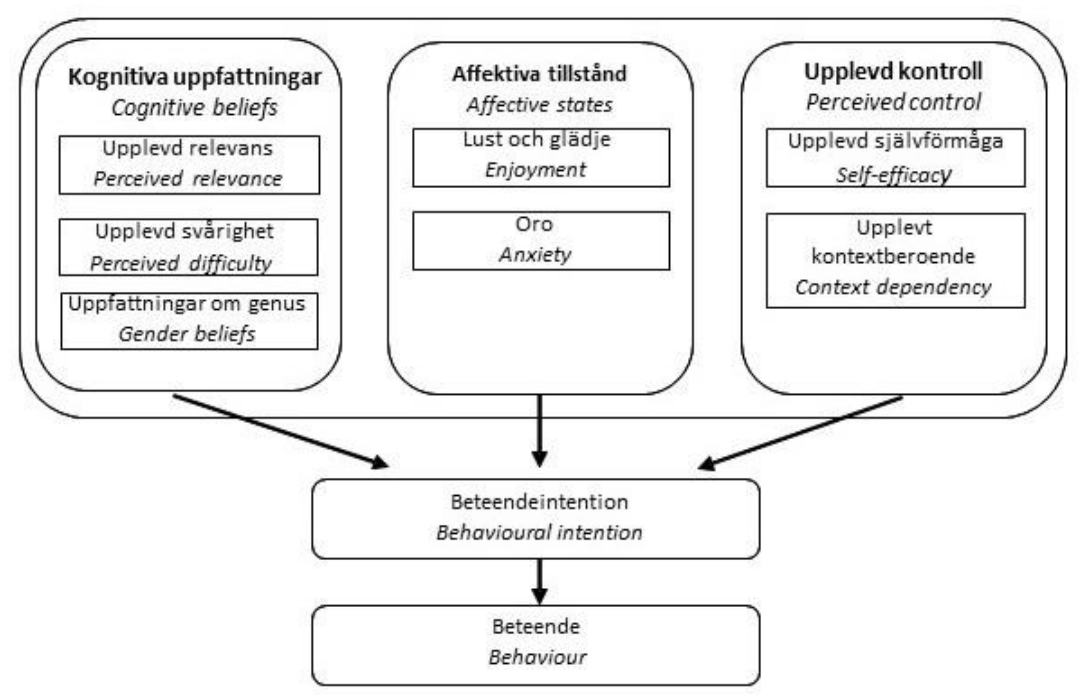

Figur 1. Attitydmodellen som används som teoretisk utgångspunkt. Figuren baseras på van Aalderen-Smeets et al. (2012)

Utgångspunkten för modellen är att attityd består av tre komponenter (van Aalderen-Smeets \& Walma van der Molen, 2013). Den första delkomponenten är cognitive beliefs (kognitiva uppfattningar) och utgår ifrån uppfattningar grundade i kunskap och tänkande kring undervisning i skolan. Den består av tre delar: 
- Perceived relevance (upplevd relevans), som handlar hur relevant undervisningen anses vara.

- Perceived difficulty (upplevd svårighet), som innefattar upplevelse av den generella svårigheten i att undervisa i ämnena (inte lärarens personliga svårighet med undervisning).

- Gender beliefs (uppfattningar om genus), som inbegriper lärarens uppfattning om skillnader mellan pojkar och flickor generellt (inte om verkliga skillnader mellan individer).

Den andra delkomponenten är Affective states (känslomässiga förhållanden) och innefattar både positiva och negativa känslor som en lärare upplever i sin undervisning. Dessa delas upp i två kategorier:

- Enjoyment (behag, glädje), som handlar om lärarens känsla av behag och att vara tillfreds i sin undervisning.

- Anxiety (oro), alltså lärarens upplevelse av missnöje och olust i undervisningen.

Den tredje delkomponenten är perceived control (upplevd kontroll) och tar upp den aspekt av attityd som innebär en lärares upplevda kontroll av sin undervisning och består av två delar:

- Self-efficacy (upplevd självförmåga), som innebär en lärares tilltro till sin egen förmåga till undervisning. Den bygger på interna beståndsdelar som kunskap och självförtroende.

- Context dependency (kontextberoende), som innebär en lärares upplevelse av påverkan av yttre faktorer i sin undervisning. Yttre faktorer är till exempel tid och material.

Attitydmodellen växte fram genom olika studier, dels en studie där lärares och lärarstudenters attityder till teknik och naturvetenskap undersöktes (Asma, van der Molen, \& van Aalderen-Smeets, 2011) och dels genom en litteraturgenomgång, vartefter modellen utvecklades vidare med hjälp av psykologiska teorier (van Aalderen-Smeets et al., 2012). Upplevd kontroll visade sig i studierna vara centralt för lärare och modellens tredje del, som handlar om både inre och yttre kontroll, gör modellen anpassad för just lärare. Det är den delen av modellen och lärarnas upplevda kontroll som är i fokus i artikel 2. 


\section{Tidigare forskning om lärares attityder till teknik och teknikundervisning}

Det har varit aktuellt att fundera kring och tala om attityder till teknikundervisning sedan införandet av det obligatoriska teknikämnet. Redan vid planeringen av införandet i Lgr 80 fanns farhågan att det skulle innebära problem på olika plan, när det gällde lärares kunskap och utbildning, brist på resurser och klassrum och negativa attityder till det undersökande arbetssätt som ämnet skulle innebära (Andersson, 1988).

Inom den teknikdidaktiska forskningen är elevers attityd till teknik ett område som studerats sedan 80-talet och som fortfarande utforskas. Forskningsområdet går under benämningen PATT (Pupils' attitude towards technology). Det startades upp av Raat and de Vries (1986) och har sedan utvecklats i olika länder. Till grund för detta forskningsområde ligger en elevenkät som innehåller frågor om intresse och attityd till teknik och som berör områden som karriär och könsmönster, och om teknik upplevs som svårt eller tråkigt. För att öka förståelsen av enkäten och betydelsen av elevernas svar, har en svensk studie gjorts och resultaten visar hur enkäten kan förbättras för att passa in i en modern kontext (Svenningsson, Hultén, \& Hallström, 2018). Elevers attityd till teknik har blivit en fråga som ständigt är aktuell.

När det gäller tekniklärares attityder till teknik och teknikundervisning finns det inte någon övergripande forskning av området liknande det ovan beskrivna forskningsområdet kring elevers attityder. Däremot har ett antal studier, rapporter och bokkapitel skrivits om olika delaspekter av attityd och om olika delar av teknikundervisning. Ett antal av dessa presenteras och sammanfattas i de kommande avsnitten.

\section{Lärarstudenters attityder}

En relativt tidig studie som tog upp tekniklärares syn på och attityd till sitt ämne, genomfördes i Holland i slutet av 1980-talet, inför införandet av Teknik som ett skolämne 1992 (De Vries, 1991). Studien gjordes i linje med de studier som tidigare genomförts med elever (PATT) och som nämnts ovan (Raat \& de Vries, 1986). 89 lärarstudenter i teknik från tre olika lärarutbildningar i Holland genomförde en enkät. De flesta som svarade var män. Studenternas attityd studerades genom fem aspekter av attityd; intresse, genus, hur pass viktigt det är, svårighetsgrad och plats i läroplanen. Resultatet visade att studenterna generellt var positiva till teknik. Författaren kallar dem kritiskt positiva. 
Svaren visade att män är intresserade av teknik i högre grad än kvinnor. Studenterna ansåg att teknik är något för både män och kvinnor och att teknik är viktigt. De tyckte att teknik inte är allt för svårt, och att det bör vara en del av läroplanen. Genom statistisk analys visades att studenter med en god förståelse av vad teknik är också har en mer positiv attityd. Liknande resultat hade tidigare visats i studier inom PATT, då elevers attityder undersökts.

En svensk studie, genomförd drygt 20 år senare, visade att både studenter med negativa och med positiva erfarenheter från teknikundervisningen under sin egen skolgång som vuxna hade en positiv attityd till att arbeta med teknik i förskolan (Hedlin \& Gunnarsson, 2014). Studien genomfördes med 79 förskollärarstudenter. Studenterna hade blandade erfarenheter av teknik från sin egen skoltid. Det framkom att vissa upplevt teknikundervisningen tråkig och att andra upplevt den mer positiv. Dessutom hade många upplevt teknikundervisningen som fokuserad på manlig teknik. Materialet samlades in genom en skriftlig uppgift, som var en del av deras lärarutbildning, där studenterna fick beskriva sina erfarenheter utifrån ett antal öppna frågor.

\section{Lärares attityder - följder för eleverna}

I en litteraturöversikt där elevers attityd till naturvetenskap var i fokus (Osborne et al., 2003), framkom läraren som en faktor med stor betydelse. Osborne et al. (2003) påvisade bland annat studier som visar att en entusiastisk lärare bidrar till god undervisning och att en lärare ska undervisa i de delar av ämnet som han eller hon känner sig säker på och bekväm i, för att bidra till god undervisning. En annan intressant aspekt som lyfts är att lärare som undervisar i flera ämnen inte är lika entusiastiska och hängivna till alla ämnen. I ett exempel från en studie i England var lärarna intresserade av biologi, vilket ledde till att fysikundervisningen blev sämre, då lärarna inte visade samma intresse och entusiasm. Även i Sverige undervisar lärare i flera ämnen, och en kombination av NO-ämnen och teknik är vanlig. En ytterligare slutsats som Osborne et al. (2003) kom fram till är att det är viktigt att rekrytera och behålla kunniga och entusiastiska lärare för att förbättra undervisningen.

I en enkätundersökning med 200 speciallärare (Allinder, 1994) undersöktes lärarnas upplevda självförmåga. Två aspekter av upplevd självförmåga kom fram; Personal efficacy - om lärarens upplevda självförmåga att förändra studenter, och Teaching efficacy - lärarens uppfattning om utbildningens och skolans möjlighet att förändra och utveckla barn oberoende av hemförhållanden. Resultaten pekade på att 
lärare med högre tilltro till sin egen förmåga att undervisa med högre sannolikhet provade nya sätt att undervisa, var mer planerande och organiserande i mötet med studenter samtidigt som de bemötte studenterna på ett mer rättvist och säkert sätt och även upplevdes mer trygga och entusiastiska. Teaching efficacy relaterades till självförtroende och entusiasm till undervisning.

\section{Lärares attityder - Exemplet Nya Zeland}

På Nya Zeland har man ett teknikämne som påminner om det svenska och där är också det teknikdidaktiska forskningsområdet relativt starkt. Därför finns intressanta studier som berör lärares attityder att lyfta fram.

När teknik skulle införas som ett nytt ämne på Nya Zealand intervjuade Jones and Carr (1992) 30 lärare för att ta reda på deras uppfattningar om teknikundervisning. Lärarna visade sig tolka ämnet utifrån sina egna erfarenheter, såsom intressen, sina upplevelser i och utanför skolan och hur länge de undervisat. Lärarna utgick från de ämnen de undervisade i. Lärare i naturvetenskap såg till exempel teknik som en metod för att undervisa i naturvetenskap medan samhällsvetenskapliga lärare lyfte de mänskliga aspekterna av teknikämnet och vikten av att göra eleverna medvetna om teknikens roll i samhället. Lärare som befann sig i början av sitt yrkesliv berättade om hur de under de första åren planerade att fokusera på sin bas och hur de senare skulle komma att lägga till tekniken, som alltså sågs som något extra. De lärare som deltagit i någon slags kompetensutveckling kände sig mer trygga i införandet av det nya ämnet. Författarna konstaterar att de föreställningar lärarna bär med sig genom sina erfarenheter kommer att influera implementeringen av ämnet. Lärarna har inte hela den breda bilden av teknikämnet, så vid införandet av den nya kursplanen och vid utvecklingen av teknikämnet måste hänsyn tas till lärarnas och skolornas utgångspunkter och förutsättningar.

När teknikämnet varit obligatoriskt i tre år i den Nya Zeeländska grundskolan gjordes en studie av lärarnas erfarenheter (Jones, Harlow, \& Cowie, 2004), baserad på en enkät som besvarats av 851 lärare. Överlag visade resultatet att lärarna var positiva till att undervisa i det nya ämnet teknik. Lärarna fick besvara frågor om sitt självförtroende i teknikundervisning, och majoriteten upplevde sig vara medelmåttigt säkra, en mindre grupp kände sig osäkra och ungefär 20 \% upplevde hög säkerhet i sin teknikundervisning. När det gäller kursplanen så upplevde ungefär hälften av lärarna att den var användarvänlig. Lärarna som undervisade de äldsta eleverna ville gärna se förändringar som 
gjorde kursplanen enklare att förstå, samt fler bedömnings- och undervisningsexempel. En upplevd svårighet som rapporterades var att få tag i de resurser och den utrustning som behövdes, något som framkom speciellt bland de som undervisade yngre elever. Man upplevde det också svårt att hinna med tekniken, i en redan fylld läroplan. Fortbildning visade sig vara en god hjälp vid implementeringen av ett nytt ämne.

\section{Lärares attityder - kontextuella faktorer}

En studie visar att svenska tekniklärare under början av 2000-talet hade en kluven förståelse av kursplanen i teknik. Det var svårt att hitta en form och en plats för teknikundervisningen, samtidigt som lärarna ansåg att det var ett viktigt ämne. Svårigheterna förklaras med att lärarna hade otillräcklig kompetens och också med organisatoriska omständigheter. Lärarna beskrev i studien att de kände sig isolerade och inte hade någon att diskutera teknikundervisning med. Författarna beskriver att utfallet av själva teknikundervisningen ser väldigt olika ut mellan olika skolor, vilket beror på olika faktorer och omständigheter såsom organisation, ledarskap, kollegor och skolkultur (MännikköBarbutiu, 2011).

Har tekniklärare sämre förutsättningar än andra lärare? Det är en av de frågor som ställdes av Nordlander (2011). Teknikämnet beskrivs som ett nedprioriterat ämne vilket skulle kunna fă konsekvenser för framtida utveckling inom samhället och industrin. Drygt 300 lärare besvarade en webbaserad enkät under läsåret 2007-2008. Av dessa lärare svarade strax över 50 \% att de känner sig säkra i att undervisa i teknik. Nordlander tror att lärarna i urvalet är något mer säkra än lärare överlag, då de deltagande lärarna har varit delaktiga i någon aktivitet eller kurs inom teknik för lärare på Högskolan i Gävle. Siffrorna visar dock att en stor del ändå anser sig vara osäkra, eller varken säkra eller osäkra. Vidare ansåg drygt hälften av lärarna att de inte hade tillgång till lämpliga lokaler och nästan lika många att det fanns brister i utrustningen. Författaren menar att kombinationen av brist på säkerhet $\mathrm{i}$ undervisningen och brist på goda lokaler och utrustning blir en kombination som kan leda till "allvarliga pedagogiska konsekvenser" (Nordlander, 2011, s. 97). Lärarna i undersökningen uppfattade teknik som ett ämne med låg status. Allra högst status jämfört med teknikämnet ansågs matematik, svenska och engelska ha.

I en brittisk studie (Bell, Martin, Woff, \& McLain, 2016) beskrivs hur några lärare i studien upplevde att kontextuella förutsättningar blivit sämre både när det gäller material och status. En lärare berättade 
att situationen såg bättre ut för 20 år sedan, då det fanns en arbetsbänk och verktyg i klassrummet. De resurserna finns inte längre. En annan lärare beskrev hur teknik (på engelska Design and Technology) inte behandlas som ett fristående ämne, utan mer som en belöning i slutet av en arbetsperiod. Majoriteten av deltagarna svarade att de producerar sitt eget undervisningsmaterial. Studien visar också att det inte undervisas i teknik i så hög utsträckning som det vore önskvärt. Studien genomfördes med lärare för lägre åldrar i England och Wales, och både kvantitativ och kvalitativ metod användes.

När fem skolor i Australien införde mekatronik med Legorobotar i undervisningen studerades lärarnas attityder i samband med detta (Nicholas \& Ng, 2012). Även i denna studie pekade en del av resultatet på betydelsen av resurser, hur externa faktorer, så som tid, ekonomiska resurser, experthjälp och tillgång till datorer påverkade. I studien ingick både kvinnor och män. De flesta var tekniklärare, någon var ITlärare och två var NO-lärare. Resultatet visade vidare att lärares intresse och entusiasm har större betydelse för genomförandet än fysiska förutsättningar som klassrumsmiljö. Tid visade sig vara viktigt, både för planeringen och för genomförandet. Till exempel berättade en lärare att han fick jobba hemma 2-4 timmar per kväll för att kunna genomföra projektet. En intressant slutsats av projektet var att lärare behöver nätverk för att mötas och dela erfarenheter, när de inte har tillgång till experthjälp.

Mattsson (2005) jämförde lärare med lärarutbildning i teknik med lärare utan lärarutbildning i teknik. Studien visade bland annat att lärarna med lärarutbildning i teknik i högre grad utgick från kursplanen i sin undervisning än lärare utan lärarutbildning i teknik. De var också mer trygga i sin kompetens, och mer nöjda med hur teknikundervisningen bedrevs, kunde förankra ämnet på ett bättre sätt på skolan, samt införskaffa det material de behövde, i jämförelse med lärarna utan lärarutbildning i teknik.

\section{Lärares attityder - Self-efficacy}

I en litteraturstudie från 1998 undersökte Tschannen-Moran et al. (1998) self-efficacy hos lärare. De använde begreppet teacher efficacy, vilket definieras som i vilken utsträckning en lärare tror att han eller hon har kapacitet att påverka elevernas prestationer. Studien visade att denna tro på sig själva hos lärare både hade betydelse för elevernas resultat och för lärarnas egna tankesätt. Vidare så var denna tro på sig 
själva hos lärare också var svår att sätta ord på (Tschannen-Moran et al., 1998). Teacher efficacy handlar alltså om lärares självförmåga.

I en svensk studie undersöktes tekniklärares självförmåga inom bedömning (Hartell, Gumaelius, \& Svärdh, 2015). Med hjälp av enkäter jämfördes lärare med och utan lärarutbildning i teknik. Författarna drog slutsatsen att lärare med lärarutbildning i teknik uttryckte en högre grad av självförmåga när det gäller bedömning i teknik, och likaså uttryckte de en större självförmåga när de beskrev för sina elever vad som förväntades av dem än lärare utan lärarutbildning i teknik. Utbildade lärare använde också kursplanen i högre utsträckning än andra.

Just självförmåga visade sig ha en hög effekt för lärares generella attityd till teknik och teknikundervisning. Det var en av slutsatserna i en holländsk studie om lärares kunskap (Rohaan, Taconis, \& Jochems, 2012). I studien beskrevs två typer av kunskap; ämneskunskap (innehåll, subject matter knowledge ) och pedagogisk ämneskunskap (om undervisningsstrategier, undervisningens syfte, elevers uppfattningar och kunskap, pedagogical content knowledge) (Shulman, 1986). Båda sorternas kunskap är viktiga i lärarutbildningen eftersom de bidrar till ökad upplevelse av självförmåga och självförtroende hos lärarna. Det gestaltas som en positiv cirkel, där positiv attityd ökar antalet teknikaktiviteter i klassrummet, vilket i sin tur ger läraren mer erfarenhet och ökade kunskaper. Erfarenhet och kunskaper bidrar sedan till positiv attityd.

Självförmåga (self-efficacy) handlar just om en persons upplevda förmåga att klara av något (Bandura, 1997), medan självförtroende (confidence) kan beskrivas som en känsla, en känsla av att klara av en uppgift utifrån de förutsättningar man har (Holroyd \& Harlen, 1996). I en skotsk studie från 1993 undersöktes lärares självförtroende (Holroyd \& Harlen, 1996). Med hjälp av enkäter undersöktes 514 lågoch mellanstadielärares självförtroende i olika ämnen. Resultatet visar att lärarna upplever lågt självförtroende i naturvetenskap och teknik, jämfört med andra ämnen. Manliga lärare upplevde högre självförtroende än kvinnor. Erfarna lärare upplevde lägre självförtroende än nyutexaminerade när det gäller naturvetenskap och teknik, medan de tvärt om kände sig mer självsäkra med åren inom andra ämnen som till exempel engelska och matematik. Författarna menar att lärare hanterar bristen på självförtroende genom att fokusera mer på det ämnesinnehåll som de känner sig säkra på, och mindre på de delar de känner sig osäkra på.

Andra aspekter av självförtroende kommer fram i en studie där tekniklärares uppfattningar och förståelse av STEM (Science, Technology, Engineering and Mathematics) studeras. Lärare med högt själv- 
förtroende visar sig undervisa på ett sätt som uppmuntrar risktagande och leder till verklig problemlösning. De med lägre självförtroende och förståelse av STEM håller sig till styrda uppgifter, vilket begränsar undervisningen (Bell, 2016). 



\section{Kapitel 5}

\section{Metod}

De två studierna är av olika karaktär och därför används olika metoder i artiklarna. Utgångspunkten i artikel 1 är att få en övergripande bild av lärares attityd. Därför har ett kvantitativt angreppssätt valts och analysen bygger på statistiska metoder. I den andra artikeln är syftet att få en djupare förståelse av attityd hos lärare, därför är den studien av kvalitativ karaktär och utgår från intervjuer med 10 lärare. Den fördjupar därmed vissa aspekter av artikel 1. De båda artiklarnas olika karaktär och olikheterna i metodvalen bidrar till den bredare förståelsen av tekniklärarnas upplevelser av teknikundervisning.

\section{Metod i artikel 1}

\section{Deltagare och datainsamling}

Målgruppen för studien var lärare i svensk grundskola som undervisar i teknik, vilket var ca 16000 personer år 2013/14 (Skolverket, 2017). En enkät skickades ut till 4000 lärare, varav 1367 besvarade den. Av dessa fick 214 sållas bort, eftersom de svarat att de inte undervisade, eller inte hade undervisat i ämnet teknik. Totalt svarade alltså 1153 lärare på enkäten, varav 79,5 \% var kvinnor och resten, 20,5 \%, var män. Dessa personer representerade 234 av Sveriges 290 kommuner. Vanligast i Sverige är att de flesta tekniktimmarna är utlagda i år 7-9, men i denna undersökning undervisade den största delen av lärarna i år 4-6. Vid tidpunkten då materialet samlades in krävdes utbildning i teknik för att vara behörig, och drygt hälften av lärarna i studien $(51,3$ \%) svarade att de var behöriga i att undervisa i teknik.

Datainsamlingen genomfördes i april 2012, av Demoskop, ett företag som gör marknadsundersökningar i Sverige. Enkäten skapades av det nationella resurscentrumet i teknik, Centrum för tekniken i skolan (CETIS), tillsammans med Teknikföretagen. Teknikföretagen är en branschorganisation som representerar 3600 företag och bland annat har i uppdrag att få svenska ungdomar intresserade av teknikutbildningar. Enkäten hade utvecklats stegvis genom mindre undersökningar bland tekniklärare av CETIS från 1998 till 2009. En sammanställning av svaren från 2012 finns i rapporten, "Teknikämnet i träda" (Teknikföretagen, 2012). 
Enkäten som skickades ut med e-post bestod av 21 frågor och påståenden med svarsalternativ och en öppen frågeställning. Flera av frågorna hade följdfrågor, så totalt bestod enkäten av 46 frågor och påståenden. I denna studie behandlas 32 frågor och påståenden från enkäten, eftersom dessa ansågs relevanta för studiens syfte. Alla frågor som finns med som grund i denna studie har svarsalternativ, men är av olika karaktär. 10 frågor bygger på fasta svarsalternativ, som t.ex. man/kvinna eller ja/nej. De övriga 22 frågorna är likertskalor mellan 1 och 6, som representerar motsatser. Värdet 1 kan t.ex. motsvara "Håller inte alls med", medan värdet 6 motsvarar "Håller helt med".

\section{Analysmetoder}

Metoden i den första delstudien är kvantitativ och innefattar statistiska analyser. För dessa analyser användes programmet SPSS 22. Metoden är tredelad och varje steg beskrivs här i korthet, se gärna Artikel 1 för mer detaljer.

Det första steget innebar att undersöka lärarnas svar på de frågor som handlade om attityder för att ta reda på om det fanns underliggande strukturer i deras sätt att svara. Den analys som gjordes heter faktoranalys, och är en metod som används för att hitta relationer mellan ett antal påståenden. Resultatet består av underliggande dimensioner av det som studerats, i detta fall attityder. Det innebär att man istället för att titta på ett antal påståenden var för sig, kan hitta samhörighet mellan påståendena, och studera dem i grupper, så kallade faktorer. 17 påståenden från enkäten, som alla handlade om attityd, användes som underlag, och dessa redovisas i figur 2. Under genomförandet visade sig ett påstående inte passa in i helheten (Det kan vara svårt att hinna med teknikundervisning), det fanns alltså ingen samhörighet mellan detta påstående och övriga 16 påståenden. Det innebär att detta påstående handlar om något annat än vad som ryms inom de fyra faktorer som analysen resulterade i. Påståendet togs därefter bort (j.f.r. Pett, Lackey, \& Sullivan, 2003) och analysen gjordes på de återstående 16 påståendena. Detta steg resulterade i fyra faktorer. De fyra faktorerna återspeglar fyra dimensioner av attityd till teknikämnet och teknikundervisning. Varje faktor fick ett värde som togs fram genom att räkna ut medelvärdet för de ingående påståendena. Varje lärare fick därmed fyra värden, ett för varje faktor. Dessa faktorer beskrivs i resultatdelen. Figur 3 illustrerar detta steg. 
1. Hur nöjd är du totalt sett med hur teknikundervisningen bedrivs på din skola?

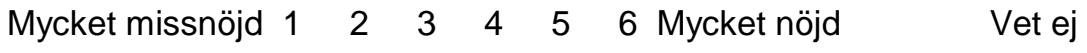

Här följer några påståenden om teknikämnet, hur väl stämmer dessa överens med din uppfattning?

$\begin{array}{llllllll}\text { Stämmer inte alls } & 1 & 2 & 3 & 4 & 5 & 6 & \text { Stämmer mycket väl } \quad \text { Vet ej }\end{array}$

2. Det är bra att Teknik är obligatoriskt i hela grundskolan

3. Teknik är ett viktigt skolämne

4. Ledningen för min skola vill utveckla teknikämnet

5. Teknikämnet kommer få ökad betydelse i framtiden

6. Teknikkunskaper är generellt viktiga för eleverna och deras framtid

Hur stor betydelse har följande faktorer på hur du bedriver undervisning i teknik?

Ingen betydelse alls $1 \quad 2 \quad 3 \quad 3 \quad 4 \quad 5 \quad 6$ Mycket stor betydelse Vet ej

7. Mitt eget intresse/kunskap kring olika teknikområden

8. Kursplanens centrala innehåll

9. På min skola finns väl inarbetade arbetsområden i teknik

Hur väl stämmer följande påståenden överens med din uppfattning?

$\begin{array}{llllllll}\text { Stämmer inte alls } & 1 & 2 & 3 & 4 & 5 & 6 & \text { Stämmer mycket väl } \\ \text { Vet ej }\end{array}$

10. På min skola har vi gott om bra material för teknikundervisning

11. Det kan vara svårt att hinna med teknikundervisning

12. Jag tycker kursplanens centrala innehåll är en bra utgångspunkt för undervisningen

13. Kunskapskraven är tydliga

14. Jag har den utbildning som krävs för att kunna bedriva en bra teknikundervisning

15. Jag känner mig trygg $i$ att undervisa $i$ teknik

16. Jag får den utvecklingstid $i$ ämnet jag behöver

17. Jag brinner för ämnet teknik

Figur 2. De 17 påståenden från enkäten som analyserades med faktoranalys. 


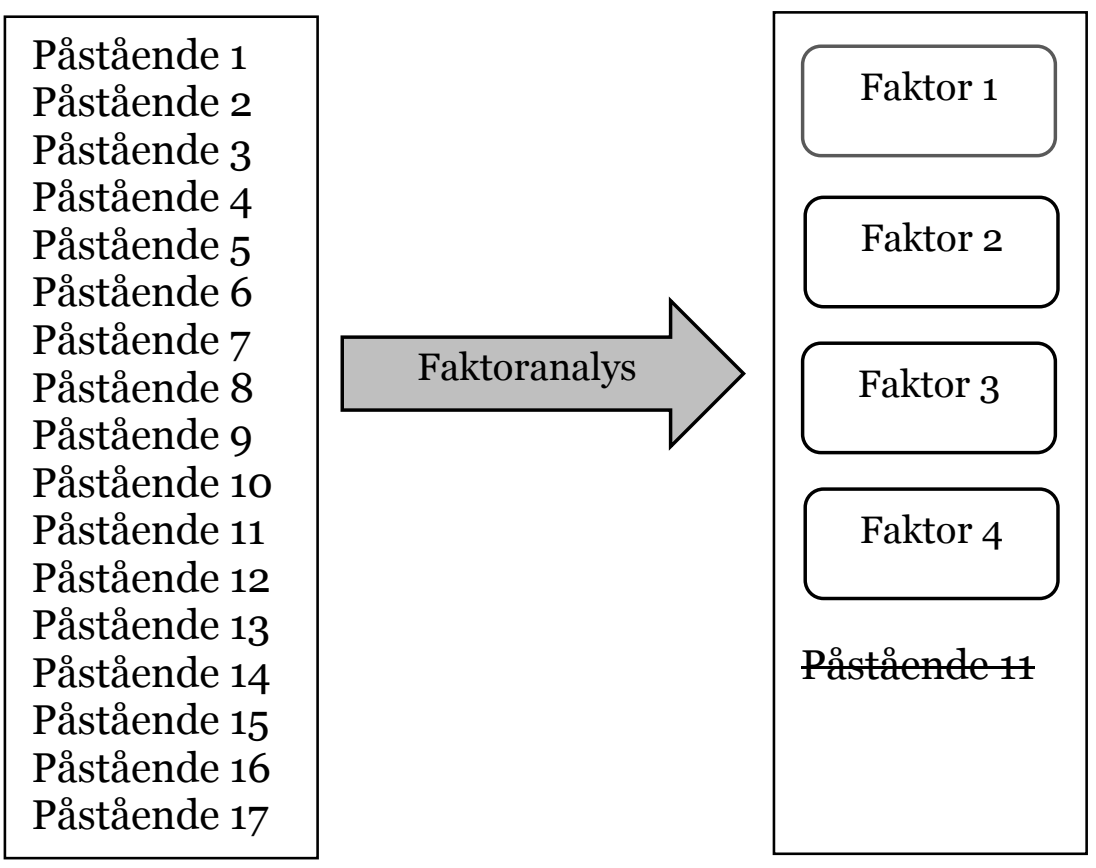

Figur 3. Illustration av faktoranalysen.

Steg två gick ut på, utifrån de faktorer som identifierats i steg ett, att ta reda på om det fanns grupperingar, alltså liknande attityd hos grupper av lärare. För att göra detta användes klusteranalys. Klusteranalys går ut på att hitta grupperingar i en datamängd, genom att hitta likheter i datan. Resultatet innebär en uppdelning av lärarna i olika grupper, där grupperna skiljer sig åt i attityd. Inom varje grupp har lärarna liknande attityder. Som mått på attityder används lärarnas värden på de fyra faktorerna (från steg 1). Med hjälp av programmet SPSS togs i detta steg reda på vilka grupper, kluster, som fanns i materialet, med utgångspunkt i lärarnas attityd (värde på de fyra faktorerna). Inom ett kluster hittar man då lärare med liknande attityd. Med hjälp av olika varianter av hierarkisk klusteranalys, som ger en slags trädstruktur där grupper kan identifieras (Mooi \& Sarstedt, 2011), togs lämpligt antal kluster fram. Genom Ward's method (Hair, Black, Babin, \& Anderson, 2010) och genom att studera det diagram som SPSS-körningen resulterade i, undersöktes lämpligt antal kluster 
ytterligare. Därefter användes också metoden med K-mean klusteranalys för att bestämma klusterlösningarna. Sedan kontrollerades halva materialet (slumpvis utvalt) ännu en gång med metoden K-mean klusteranalys, för att säkerställa fördelningen av lärarna i klustren (Clatworthy, Buick, Hankins, Weinman, \& Horne, 2005), vilket dessutom pekar på både stabilitet och validitet.

Det tredje steget handlade om att försöka ta reda på vilka egenskaper och förutsättningar hos lärarna och deras undervisningskontext som är viktiga för vilket kluster de befinner sig i. Detta gjordes med en metod som kallas multinominal logistisk regressionsanalys (Field, 2009). Denna metod går ut på att testa om en variabel kan förutsäga vilken kategori ett objekt kommer tillhöra. I detta fall testas olika variablers möjlighet att förutspå vilket kluster en lärare tillhör, alltså vilken attityd en lärare har. De variabler som testades med denna metod var av tre typer, variabler som handlar om lärarens inställning till faktorer som påverkar undervisningen, variabler som återspeglar lärarens bakgrund och variabler som handlar om skolkontexten. Alla variabler som analyserades redovisas i tabell 1 . Om vi till exempel tar variabeln utbildning så ger denna metod ett värde som talar om med vilken sannolikhet de lärare som har lärarutbildning i teknik kommer att tillhöra ett visst kluster, jämfört med dem som inte har tekniklärarutbildning. Resultatet av analysen ligger till grund för en diskussion om möjliga förklaringar till lärares attityder till teknikundervisning. 
Kapitel 5

Tabell 1

\begin{tabular}{|c|c|c|}
\hline \multirow{2}{*}{$\begin{array}{l}\text { Kontinuerliga variabler } \\
\text { Variabler som påverkar } \\
\text { undervisningen }\end{array}$} & \multicolumn{2}{|c|}{ Kategoriska variabler } \\
\hline & $\begin{array}{l}\text { Variabler som beror på } \\
\text { lärarens bakgrund }\end{array}$ & $\begin{array}{l}\text { Variabler som beror på } \\
\text { skolkontexten }\end{array}$ \\
\hline $\begin{array}{l}\text { Läromedlens upplägg har } \\
\text { stor betydelse för hur jag } \\
\text { bedriver teknikundervisning- } \\
\text { en }\end{array}$ & $\begin{array}{l}\text { Är du, enligt de nya } \\
\text { reglerna, behörig att } \\
\text { undervisa i ämnet } \\
\text { teknik? }\end{array}$ & $\begin{array}{l}\text { Finns det någon över- } \\
\text { gripande ämnesplane- } \\
\text { ring i teknik baserat på } \\
\text { nya läroplanen, Lgr 11, } \\
\text { på din skola? }\end{array}$ \\
\hline $\begin{array}{l}\text { Inspiration från andra } \\
\text { material, tävlingar m.m. har } \\
\text { stor betydelse för hur jag } \\
\text { bedriver teknikundervisning- } \\
\text { en }\end{array}$ & $\begin{array}{l}\text { Har du deltagit i någon } \\
\text { form av kompetensut- } \\
\text { veckling i ämnet tek- } \\
\text { nik? }\end{array}$ & $\begin{array}{l}\text { Hur bedrivs huvudsakli- } \\
\text { gen teknikundervis- } \\
\text { ningen vid din skola } \\
\text { idag? }\end{array}$ \\
\hline $\begin{array}{l}\text { Kollegor har stor betydelse } \\
\text { för hur jag bedriver teknik- } \\
\text { undervisningen }\end{array}$ & $\begin{array}{l}\text { Undervisar du årskurs } \\
1-3 ?\end{array}$ & $\begin{array}{l}\text { Har teknikämnet ett } \\
\text { fastställt antal timmar i } \\
\text { undervisningen på din } \\
\text { skola? }\end{array}$ \\
\hline $\begin{array}{l}\text { Elevernas frågor har stor } \\
\text { betydelse för hur jag bedri- } \\
\text { ver teknikundervisningen }\end{array}$ & $\begin{array}{l}\text { Undervisar du årskurs } \\
4-6 ?\end{array}$ & \\
\hline \multirow{3}{*}{$\begin{array}{l}\text { Närområdets möjligheter till } \\
\text { utflykter och inspiration har } \\
\text { stor betydelse för hur jag } \\
\text { bedriver teknikundervisning- } \\
\text { en }\end{array}$} & $\begin{array}{l}\text { Undervisar du årskurs } \\
\text { 7-9? }\end{array}$ & \\
\hline & $\begin{array}{l}\text { Vilket år tog du din } \\
\text { lärarexamen? }\end{array}$ & \\
\hline & $\begin{array}{l}\text { Är du man eller } \\
\text { kvinna? }\end{array}$ & \\
\hline
\end{tabular}




\section{Metod i artikel 2}

\section{Urval, deltagare och datainsamling}

Även i denna delstudie är målgruppen lärare som undervisar i teknik i den svenska grundskolan. Studien, som har en kvalitativ forskningsansats, bygger på intervjuer. Ungefär ett 30-tal lärare blev tillfrågade om att delta, och de tio som tackade ja gav de svar som ligger till grund för studien. Deras gemensamma nämnare är att de alla undervisar i teknik. Annars representerar de tre olika kommuner, det är både män och kvinnor i olika åldrar, de representerar alla tre stadier i grundskolan och de flesta (sex st) undervisar i årskurs 4-6, precis som i artikel 1. Bland de intervjuade finns både lärare med och utan legitimation i teknikämnet. Tabell 2 ger en överblick av de deltagande lärarna.

Tabell 2

\begin{tabular}{llllll}
\hline Namn & Födelseår & Examensår & $\begin{array}{l}\text { Undervisar } \\
\text { i årskurs }\end{array}$ & $\begin{array}{l}\text { Tekniklärar- } \\
\text { utbildning }\end{array}$ & $\begin{array}{l}\text { Lärarlegitimation } \\
\text { i teknik }\end{array}$ \\
\hline Albert & 1971 & 1999 & $4-6$ & Nej & $\begin{array}{l}\text { Väntar på beslut om } \\
\text { att få legitimation }\end{array}$ \\
Belinda & 1965 & 2006 & $4-6$ & Nej & $\begin{array}{l}\text { Väntar på beslut om } \\
\text { att få legitimation }\end{array}$ \\
Carl & 1984 & 2014 & $7-9$ & $\mathrm{Ja}$ & Ja \\
Diana & 1959 & 1999 & $7-9$ & Nej & Ja \\
Ellen & 1976 & 1999 & $1-3$ & Nej & Nej \\
Fiona & 1966 & 2011 & $4-6$ & Nej & Nej \\
Greg & 1958 & 1990 & $7-9$ & Nej & Nej \\
Harold & 1973 & 1996 & $4-6$ & Ja & Ja \\
Irene & 1964 & 2001 & $4-6$ & Ja & Ja \\
Jenny & 1971 & 1996 & $4-6$ & Ja & Ja \\
\hline
\end{tabular}

Intervjun var semistrukturerad och utgick från den intervjuguide som finns i bilaga 1. Frågorna handlade i stort om lärarnas upplevelser, erfarenheter och tankar kring teknikundervisning. Med var och en av lärarna gjordes det upp om lämplig tid och plats för intervjun och utfallet blev att varje intervju genomfördes på respektive lärares arbetsplats. Det var positivt eftersom läraren var i sin egen arbetsmiljö och jag som intervjuade fick bilda mig en uppfattning om arbetsplatsen. 
Varje intervju tog mellan 45 och 75 minuter. Formen blev som ett samtal kring lärarens teknikundervisning med intervjuguiden som grund för samtalet, samtidigt som varje intervju fick sin egen karaktär, utifrån vad som framkom under samtalet.

I studie två intervjuades tio lärare. Det går inte att veta om någon av dessa tio var med och besvarade enkäten som ligger till grund för studie 1, då respondenterna var anonyma. Alla lärare som intervjuades i studie 2 uttalade sig om att teknikämnet var viktigt, att de tyckte om att undervisa i teknik eller något liknande i positiva ordalag. Att de valde att prata med mig om sin undervisning är också en signal om att de troligtvis har en positiv grundinställning till teknikundervisning. Att hitta lärare ur den negativa gruppen som vill vara med på en timmes intervju om teknikundervisning är svårt. Det innebär att det antagligen inte var någon av lärarna i studie 2 , som skulle ha tillhört den negativa gruppen i studie 1, och därför har vi inte heller valt att kategorisera lärarna i delstudie 2 efter de tre kategorierna som studie 1 resulterade $i$. Urvalet i de båda studierna är lärare från grundskolan, och i båda studierna undervisar de flesta av deltagarna i år 4-6. Urvalet är därmed baserat på samma kriterier som i studie 1, även om inte intervjuerna utförts med samma individer, och inte heller vid samma tidpunkt som vid insamlingen av data till studie 1 .

\section{Analysmetoder}

Alla intervjuer transkriberades och analyserades. I det kvalitativa analysarbetet användes ett hermeneutiskt synsätt, vilket kan ses som en cirkel där forskaren rör sig från enskilda delar av materialet - till helheten - och tillbaka till de enskilda delarna och så vidare, för att få en god förståelse av texten (Kvale \& Brinkmann, 2014). En tematisk analys av materialet genomfördes, utifrån Braun and Clarke (2006) enligt följande: (1) genomläsning för att lära känna texten, (2) en första kodning av intressanta avsnitt som matchade forskningsfrågorna. Vidare, (3) söktes teman, genom sortering av koderna och med ramverket i åtanke (van Aalderen-Smeets et al., 2012), fokus hamnade nu på området upplevd kontroll. Temana förfinades (4) och teman inklusive underteman gavs namn (5). Till sist (6) togs exempel från texten fram som representerade de funna temana.

Attityder är inte alltid tydligt uttalade utan kan också vara dolda. Därför ställdes inte direkta frågor om attityder till de deltagande lärarna. Istället har vi författare tolkat attityderna utifrån lärarnas svar och uttalanden. Till exempel så har uttalandet "Det är svårare att undervisa i teknik eftersom vi inte har böcker" (Albert) tolkats som kontextbero- 
ende och underkategorin resurser, eftersom brist på böcker försvårar för Albert, och därmed påverkar hans attityd. Jenny säger: "Jag tycker det är enklare egentligen [teknikundervisningen]... Jag är inkörd, jag vet vad vi ska göra”. Detta excerpt tolkades som intern kontroll och Self-efficacy, eftersom Jenny gör ett värderande uttalande där hon beskriver sin självförmåga.

Resultatet blev en bild av de tio lärarnas attityder, utifrån hur författarna till artikeln (Nordlöf, Hallström, \& Höst, 2017) tolkade deras redogörelse. Det gjordes alltså ingen analys av lärarna en och en. Trots att tio personer är en begränsad grupp, så genererades tillräckligt med information för att uppnå mättnad och för att validera de teman som växte fram. Strikt tolkat så kan vi egentligen bara uttala oss om dessa tio lärares upplevelser, men förhoppningsvis kan också dessa lärares erfarenheter och tankar hjälpa till att skapa en mer generell intersubjektiv förståelse för lärares attityder till teknikundervisning, speciellt tillsammans med resultaten från studie 1.

\section{Metoddiskussion - validitet, reliabilitet och etiska överväganden}

För licentiatuppsatsen som helhet, där de två artiklarna tillsammans utgör basen, har en typ av triangulering använts. Triangulering innebär att man tittar på ett fenomen från olika håll (Larsson, 2005). I detta fall används metodisk triangulering (Robson, 2011) som innebär att lärares attityder till teknikundervisning studerats både kvantitativt (artikel 1) och kvalitativt (artikel 2). De tolkningar som gjorts i de båda delstudierna har vid osäkra fall diskuterats av minst tre personer, så kallad observationstriangulering (Robson, 2011).

\section{Artikel 1}

I artikel 1 används statistiska metoder för att säkerställa validiteten, gällande både faktoranalysen och klusteranalysen. Förutom statistiska metoder så används också så kallad empirisk förankring (Larsson, 2005) genom hela processen och de tre författarna till artikeln reflekterade därför genom hela arbetet kring hur resultatet stämde överens med verkligheten. Likaså har validiteten kontrollerats vid olika tillfällen med en större forskargrupp i form av seminarier. Artikeln har också blivit publicerad och genomgått peer review, vilket i sig är en form av validering (Larsson, 2005). Reliabiliteten kontrolleras också statistiskt 
genom att Cronbach's alpha-värden för de fyra faktorerna testats (Field, 2009).

\section{Artikel 2}

Larsson (2005) förklarar validitet vid kvalitativ forskning med fem kriterier. Det första kriteriet för validitet är enligt Larsson (2005) diskurskriteriet, vilket innebär att andra inte finner svagheter i resultatet. I detta fall har artikel 2 genomgått peer review och blivit publicerad och arbetet i stort har prövats i olika sammanhang som till exempel seminarier.

Det andra validitetskriteriet kallar Larsson (2005) för heuristiskt värde. "En lyckad analys resulterar i ett nytt sätt att se verkligheten" (Larsson, 2005, p. 28). Detta innebär att det som presenteras, i detta fall tekniklärares attityder till sin undervisning, framstår som meningsfullt och begripligt. Motsatsen är en analys som inte tillför något nytt utan mer beskriver ett fenomen som det beskrivs i största allmänhet. Utarbetandet av nya underkategorier i attitydmodellen bidrar till ett nytt sätt att presentera lärares attityder.

Det tredje kriteriet Larsson (2005) tar upp är empirisk förankring, vilket innebär att tolkning ska överensstämma med verklighet. Att tre forskare varit inblandade i tolkningarna är ett sätt att förstärka den empiriska förankringen, liksom den systematiska kvalitativa analys som genomfördes (se avsnittet analysmetoder).

Kriterium fyra handlar om konsistens och spelet mellan helhet och delar. Det är alltså delarna som bygger upp helheten, samtidigt som helheten ger varje del sin innebörd (Larsson, 2005). Det innebär att tolkningarna inte ska motsäga något enskilt citat och att det ska finnas en harmoni $\mathrm{i}$ helheten, mellan vad lärarna säger och våra tolkningar. Till grund för detta ligger den hermeneutiska cirkeln som beskrivs i avsnittet analysmetoder, sid 32.

Det pragmatiska kriteriet handlar om konsekvenserna av resultatet, vilket brukar förtydligas med frågan "so what?". Alltså, vad innebär resultatet för praktiken? Förhoppningen är att denna licentiatuppsats kapitel "Övergripande slutsatser och implikationer" ska uppfylla detta kriterium.

\section{Forskningsetik}

Under arbetet med licentiatuppsatsen och de båda artiklarna har Vetenskapsrådets forskningsetiska principer följts (Vetenskapsrådet, 2002). De forskningsetiska principerna består av informationskravet, samtyckeskravet, konfidentialitetskravet och nyttjandekravet och 
bygger på åtta regler. Kortfattat kan man beskriva dessa regler enligt följande:

- Regel 1: information om uppgift och villkor till de deltagande, samt upplysning om frivillighet och rätt att avbryta.

- Regel 2: Forskaren ska inhämta samtycke från deltagaren.

- Regel 3: Deltagaren har rätt att bestämma om, hur länge och på vilka villkor denne deltar.

- Regel 4: Deltagaren făr inte utsättas för påverkan eller påtryckning då det gäller medverkan. Beroendeförhållande bör inte finnas mellan forskare och deltagare.

- Regel 5: uppgifter om deltagare skall ges största möjliga konfidentialitet och forskare har tystnadsplikt beträffande etiskt känsliga uppgifter.

- Regel 6: personuppgifter förvaras så att deltagare ej kan identifieras av utomstående.

- Regel 7: insamlade uppgifter făr inte användas för ickevetenskapliga syften.

- Regel 8: insamlade personuppgifter får inte användas för beslut eller åtgärder som påverkar den enskilde.

När det gäller artikel 1 övertogs ett redan insamlat material vilket ligger till grund för den studien. Den materialinsamlingen genomfördes av undersökningsföretaget Demoskop och alla deltagare besvarade webbenkäten anonymt (Teknikföretagen, 2012). I den introducerande informationstexten till webbenkäten (se bilaga 2) framgick syftet med undersökningen samt att deltagandet var frivilligt.

I den andra delstudien som mynnade ut $\mathrm{i}$ artikel 2 ansvarade jag själv för materialinsamlingen. Alla lärare som tillfrågades om att vara med upplystes om syftet med intervjuerna och att det var helt frivilligt att vara med. Vidare upplystes de deltagande om att deras svar skulle behandlas anonymt. Alla namn i denna licentiatuppsats är fiktiva. 

Kapitel 6

\section{Om studierna och deras resultat}

I licentiatuppsatsen ingår två artiklar med tekniklärares attityder i fokus. Det är två olika studier med olika datainsamling. Den första artikeln grundas på data som är insamlad med hjälp av enkäter, medan den andra bygger på intervjustudier.

\section{Artikel 1: Tekniklärares attityder till sitt ämne och dess undervisning}

Den första studien resulterade i artikel 1: Swedish Technology teacher's attitudes to their subject and its teaching (Nordlöf, Höst, \& Hallström, 2017). Syftet är att ge en bild av tekniklärares attityder till ämnet och undervisningen och att hitta förklaringar till de olika attityderna hos lärarna. Artikeln utgår från tidigare forskning som utreder vikten av lärarens attityd i undervisningen (Holroyd \& Harlen, 1996; Osborne et al., 2003; van Aalderen-Smeets \& Walma van der Molen, 2013) och som beskriver att en lärare med positiv attityd till sin undervisning och till ämnet gör ett bättre jobb i klassrummet. Resultatet är tredelat och har vuxit fram från statistiska analyser, vilka finns beskrivna i metodavsnittet. För mer detaljer kring resultatet, se artikeln.

\section{Delresultat 1- fyra aspekter av attityd till teknikämnet och teknikundervisning}

Faktoranalysen resulterade i fyra attitydaspekter, nämligen; Teknikundervisning är viktigt, Förutsättningarna för teknikundervisning är goda, Kursplanen är i fokus för teknikundervisningen och Läraren har intresse, kunskap och självförtroende. De namngavs utifrån hur de påståenden som låg till grund för aspekterna grupperade sig. Hur påståendena från enkäten grupperar sig redovisas i figur 4. För varje faktor var Cronbach Alpha-värdet minst 0,7, vilket indikerar reliabilitet för de fyra faktorerna och innebär att påståendena inom var och en av de fyra faktorerna hänger ihop.

Detta delresultat ger alltså fyra aspekter av attityd hos tekniklärare som har namngetts utifrån sina respektive innehåll. Dessa ger en bild av hur attityder till teknik och teknikundervisning kan se ut hos tekniklärare. 
I artikeln (Nordlöf, Höst, et al., 2017) redovisas faktorerna i tabell 8 (sidan 204). Tyvärr blev det ett fel i tabellen när artikeln skulle tryckas. Det rätta värdet för "\% of variance explained" ska vara $33.1 \%$.

Faktor 1 Teknikundervisning är viktigt

- Teknik är ett viktigt skolämne

- Det är bra att Teknik är obligatoriskt i hela grundskolan

- Teknikkunskaper är generellt viktiga för eleverna och deras framtid

- Teknikämnet kommer få ökad betydelse i framtiden

Faktor 2 Förutsättningarna för teknikundervisning är goda

- På min skola har vi gott om bra material för teknikundervisning

- Hur nöjd är du totalt sett med hur teknikundervisningen bedrivs på din skola?

- På min skola finns väl inarbetade arbetsområden i teknik

- Jag får den utvecklingstid i ämnet jag behöver

- Ledningen för min skola vill utveckla teknikämnet

Faktor 3 Kursplanen är i fokus för teknikundervisningen

- Jag tycker kursplanens centrala innehåll är en bra utgångspunkt för undervisningen

- Kunskapskraven är tydliga

- Kursplanens centrala innehåll

Faktor 4 Läraren har intresse, kunskap och självförtroende

- Jag känner mig trygg i att undervisa i teknik

- Jag har den utbildning som krävs för att kunna bedriva en bra teknikundervisning

- Jag brinner för ämnet teknik

- Mitt eget intresse/kunskap kring olika teknikområden

Figur 4. De fyra faktorerna och fördelningen av frågor och påståenden mellan faktorerna. I figur 2 redovisas frågeställningarna i sin helhet.

\section{Delresultat 2 - tre lärargrupper}

Klusteranalysen resulterade i tre kluster, eller grupper, av lärare. Inom varje grupp fanns likheter i lärarnas attityd till teknikundervisning. De fyra aspekterna av attityd som framkom i delresultat 1 låg till grund för 
de tre klustren, som kallades Positiva, Negativa och Blandade. Namnen bestämdes utifrån hur individerna inom varje grupp hade svarat. Resultatet sammanfattas i figur 5 .

Positiva gruppen $(\mathrm{n}=419)$ : Den här gruppen svarade relativt högt på alla fyra faktorer. De ansåg att teknikämnet är viktigt, att förhållandena för teknikundervisning var relativt bra på skolan, de hade fokus på kursplanen i sin undervisning och de upplevde sig intresserade, kunniga och hade relativt högt självförtroende.

Negativa gruppen $(n=296)$ : Dessa lärare svarade relativt lågt på alla fyra faktorer. Det innebär att de tyckte att ämnet är mindre viktigt än vad den positiva gruppen tyckte. De ansåg sig inte ha goda förhållanden för teknikundervisning på sin skola och de hade en negativ inställning till kursplanen. De svarade också att de inte upplevde så högt intresse, kunskap och självförtroende när det gäller teknikundervisning.

Blandade gruppen $(\mathrm{n}=423)$ : Precis som namnet antyder så hade den här gruppen en blandad attityd till teknikämnet och undervisningen. De tyckte att ämnet är viktigt och hade också en positiv attityd till kursplanen och lät den vara i fokus i undervisningen. Däremot upplevde de att de inte hade särskilt goda förutsättningar för att genomföra teknikundervisning och de upplevde mindre intresse, kunskap och självförtroende än den positiva gruppen.

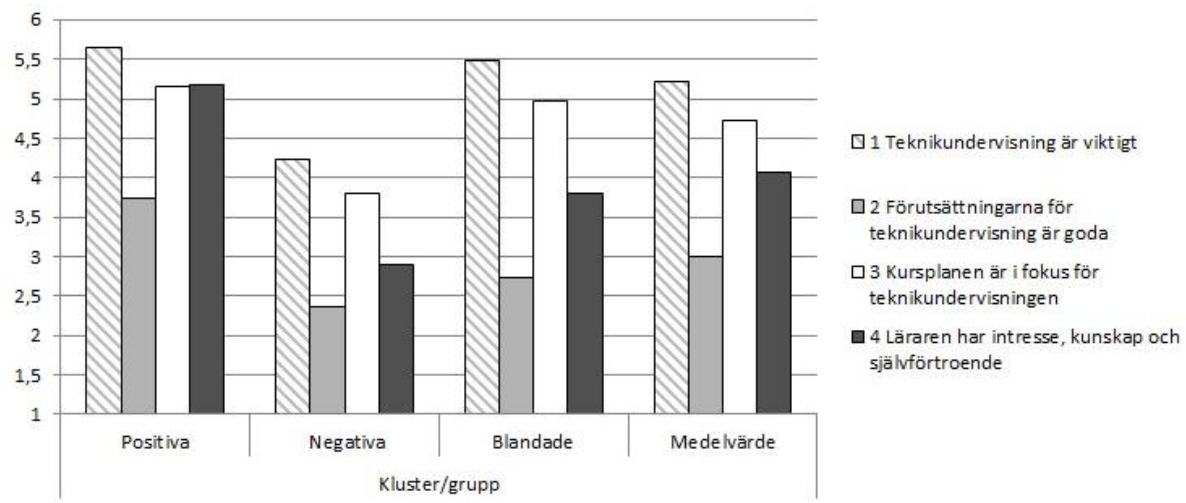

Figur 5. Resultat av klusteranalysen.

Detta delresultat visar alltså hur lärarna förhöll sig till de fyra aspekterna av attityd till teknikundervisning, och att det fanns likheter i hur de 
förhöll sig. De tre grupperna bildades utifrån lärarnas svar och inom varje grupp hade lärarna relativt lika attityd till teknikundervisning.

\section{Delresultat 3 - att förutsäga lärares attityd}

Resultatet av metoden multinominell logistisk regression var signifikant, och modellen klassade $58,5 \%$ av fallen rätt. För att göra analysen så väljs en kategori som referens, och i detta fall valdes den positiva gruppen. Det innebar att den positiva gruppen jämförts med de andra två grupperna (blandade och negativa), utifrån ett antal variabler som presenteras i kommande avsnitt. Figur 6 illustrerar en sammanfattning av variablerna med störst betydelse för grupptillhörighet. I artikel 1 finns tabeller som visar resultatet för varje undersökt variabel i tabellform. I avsnitten nedan beskrivs resultaten i korthet.

\section{Variabler baserade på lärarens bakgrund}

Den fråga som hade störst betydelse inom denna kategori var behörighet i att undervisa i teknik. När materialet samlades in hade inte lärarlegitimationen införts, så med behörighet menas att läraren genom sin lärarutbildning blivit behörig att undervisa i teknik. Lärare med behörighet hade ungefär fem gånger större sannolikhet att tillhöra den positiva gruppen än någon av de andra grupperna. Lärare med kompetensutveckling inom teknik tillhörde med mindre sannolikhet (ca 30\% sannolikhet) den negativa gruppen eller den blandade gruppen (ca 50\% sannolikhet) jämfört med lärare utan kompetensutveckling. Om läraren var man eller kvinna visade sig inte ha någon betydelse för den negativa gruppen, men sannolikheten att tillhöra den blandade gruppen var ungefär hälften så stor för män som för kvinnor. Vilka elever som läraren undervisar hade inte någon signifikant betydelse, förutom för de som undervisar årskurs 4-6. Dessa lärare har dubbelt så stor sannolikhet att tillhöra den negativa gruppen, jämfört med de som undervisar i årskurs 7-9. Lärarens examensår hade inte heller statistiskt säkerställd betydelse, förutom när det gäller dem som tog examen 1960-1979. Dessa lärare var med dubbelt så hög sannolikhet i den negativa gruppen, jämfört med de senast utexaminerade lärarna.

\section{Variabler baserade på skolkontext}

Lärare som arbetade i skolor där det inte fanns ett bestämt antal timmar för teknikämnet hade ungefär dubbelt så hög sannolikhet att tillhöra den negativa gruppen eller den blandade gruppen jämfört med de som hade ett fastställt timantal för teknikämnet. Vidare så fanns det lärare som inte visste om de hade ett fastställt antal timmar till tek- 
nikämnet eller ej, och de tillhörde med ännu större sannolikhet den negativa gruppen (ca 4 gånger) eller den blandade gruppen (ca 2,5 gånger). Om en övergripande ämnesplanering för teknik fanns på skolan tillhörde läraren med mindre sannolikhet den negativa gruppen (ca $30 \%$ sannolikhet) eller den blandade (ca $40 \%$ sannolikhet).

\section{Variabler baserade på undervisningskontext}

De frågor som denna del av resultatet bygger på besvarades genom att välja ett värde på en skala mellan 1 och 6 . Den oddskvot som anges inom parentes är i jämförelse med den positiva gruppen. Sannolikheten för en lärare att tillhöra den negativa gruppen minskade ju högre han eller hon hade svarat på någon av följande frågor: Inspiration från andra material, tävlingar m.m. har stor betydelse för hur jag bedriver teknikundervisningen $(0,69)$ och Närområdets möjligheter till utflykter och inspiration har stor betydelse för hur jag bedriver teknikundervisningen $(0,43)$. På samma sätt ökade sannolikheten att tillhöra den negativa gruppen ju högre svaret var på följande påståenden Läromedlens upplägg har stor betydelse för hur jag bedriver teknikundervisningen $(1,21)$ och Kollegor har stor betydelse för hur jag bedriver teknikundervisningen $(1,29)$. Ju lägre en lärare svarade på påståendet Elevernas frågor har stor betydelse för hur jag bedriver teknikundervisningen desto högre sannolikhet att han eller hon tillhör den negativa gruppen $(0,43)$ eller den blandade gruppen $(0,71)$. Frågorna i denna del visade sig ha minst påverkan på resultatet.

\section{Sammanfattning av delresultat 3}

Figur 6 ger en förenklad bild av resultatet och visar på de mest betydelsefulla variablerna när det gäller sannolikheten att tillhöra en viss grupp, men visar inte hur stor påverkan de olika variablerna har. Alla variabler i figuren är signifikanta. Alla variabler innebär också minst dubbel sannolikhet att tillhöra den grupp som pilen pekar på, jämfört med den variabel som jämförelsen gjorts med. Den variabel med överlägsen betydelse var behörighet i teknikämnet. För mer detaljer se artikel 1.

Resultatet pekar på att det är störst sannolikhet att läraren har en positiv inställning till teknikundervisning om han eller hon är behörig och har deltagit i kompetensutveckling inom teknikämnet. Sannolikheten för att läraren ska ha positiv attityd ökar om det på skolan finns en ämnesövergripande planering för teknikundervisningen och om ämnet har ett fastställt timantal. Resultatet visar vidare att kvinnor har lite högre sannolikhet att ha en blandad attityd till teknikundervisning. Lärare på mellanstadiet, och lärare som tog examen tidigt finns med större sannolikhet i den negativa gruppen. 


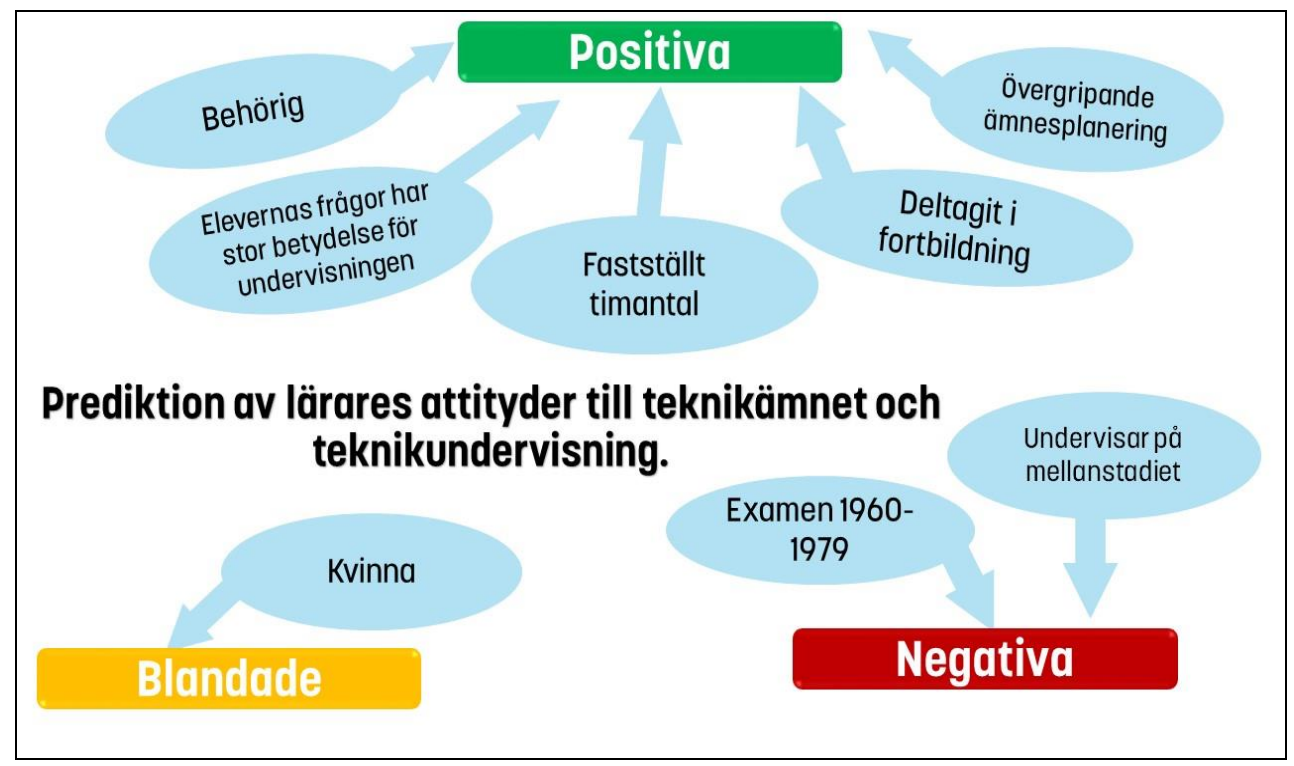

Figur 6. Förenklad bild av delresultat 3. De mest betydelsefulla variablerna när det gäller sannolikheten att tillhöra en viss grupp.

\section{Artikel 2: upplevd självförmåga och kontextberoende i teknikundervisningen}

Den andra delstudien resulterade i artikeln Self-efficacy or context dependency?: Exploring teachers' perceptions of and attitudes towards technology education (Nordlöf, Hallström, et al., 2017). I denna studie undersöktes en aspekt av lärares attityder som kallas upplevd kontroll och som består av variablerna upplevd självförmåga och kontextberoende. Som utgångspunkt användes en attitydmodell som tagits fram för att förklara lärares attityder (Sandra van AalderenSmeets et al., 2012). För att komma nära inpå och för att få en djupare förståelse för tekniklärares attityder valdes semistrukturerade intervjuer för denna studie och forskningsfrågan som var i fokus löd; Hur erfar lärarna upplevd självförmåga och kontextberoende $i$ sin teknikundervisning?

För att finna svar på frågan och för att få en ökad förståelse för attityder hos tekniklärare intervjuades tio lärare som undervisar i teknik i svensk grundskola. Intervjumaterialet analyserades och underkate- 
gorier till upplevd självförmåga och kontextberoende växte fram. Dessa redovisas i figur 7 .

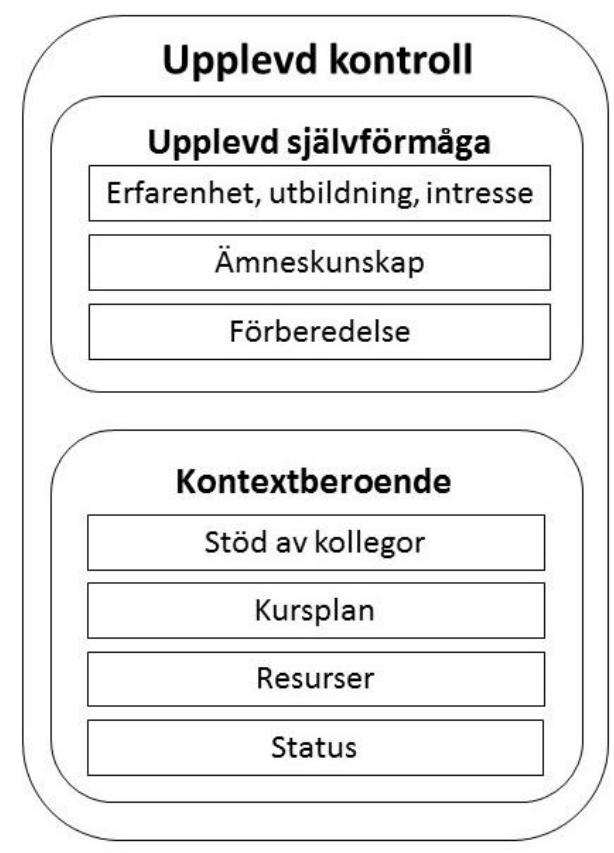

Figur 7. De underkategorier som var resultatet av analysen i artikel 2.

\section{Resultat}

Överlag talade lärarna positivt om både teknikämnet och teknikundervisning. Lärarna som intervjuades var nöjda med att undervisa i just teknik, och de ansåg det vara ett viktigt ämne. Resultatet fokuserar dock på self-efficacy och context dependency, som två aspekter av attityd.

\section{Upplevd självförmåga}

Självförmåga är inte något konstant som man har eller inte har, utan det är något som upplevs i olika grad för olika lärare, och vidare också i olika grad för en och samma lärare men i olika situationer eller inom olika områden av teknik. Den upplevda självförmågan är en del av den kontroll som en lärare erfar att han eller hon har i sin undervisning det handlar om inre upplevelser av kontroll.

Erfarenhet, utbildning och intresse - dessa tre egenskaper visade sig ha betydelse för den upplevda självförmågan, enligt vår tolkning. Vidare så såg vi att utifrån hur lärarna talade om dessa tre egenskaper 
så verkade de hänga ihop. Generellt så gav lärare utan lärarutbildning i teknik ett mer osäkert intryck än de utbildade, samtidigt som alla visade olika grad av upplevd självförmåga inom olika områden av teknikämnet.

Några av lärarna i studien talade om att de vill vara förberedda för olika situationer i klassrummet, som att kunna svara på olika frågor som eleverna ställer. Diana, som har lärarutbildning men inte i teknik, beskriver att hon i sin undervisning ser till att befinna sig inom den del av teknikämnet som hon känner sig säker på och undviker andra områden, just för att slippa besvara frågor som hon inte kan svaret på. Hon beskrev teknikämnet som ett brett ämne, där hon bara behärskar en ganska smal del av det, i jämförelse med andra ämnen som hon är utbildad i (till exempel kemi och matematik) som hon behärskar bättre. Samtidigt upplevde Diana att erfarenhet underlättar, och att hon var mer erfaren vid intervjutillfället än fem år innan dess. Jenny å andra sidan tyckte att teknik var enklare att undervisa i än andra ämnen vilket enligt henne berodde på erfarenhet.

Fiona, som inte har lärarutbildning i teknik, jämförde ämnet med matematik, ett ämne som hon läst i sin lärarutbildning. Hon beskrev att hon är säkrare i matematiken, och att hon inte på samma sätt gått in på djupet i teknikens kursplan som i matematikens kursplan. Det leder till att hon är lite försiktigare i sin undervisning i teknik, speciellt med tanke på betygssättningen. Hon berättade vidare att hon hellre gav ett lägre betyg än ett högre, som en följd av hennes osäkerhet.

Det framkom också att lärare som har läst teknik i sin lärarutbildning, upplever att det gjordes i för liten utsträckning. Deras upplevda självförmåga beror enligt dem själva inte på utbildningen, utan på deras personliga intresse i ämnet. Jenny beskrev det så här:

Nej, men det som har gjort mig till en bra tekniklärare är nog det som jag har studerat själv, mitt liv liksom. Det jag har lärt mig, läst på och skapat. Visst, utbildningen var ju, jag fick ju grunderna, det är inget snack om det, men det är inte det jag lutar mig tillbaks på, det är det andra.

Jenny beskrev sig själv som "otroligt säker" i teknik och menade att ju mer du kan om ett ämne, desto mer tycker du om ämnet. Vidare sa hon att hon till exempel inte skulle vara samma lärare om hon skulle undervisa i engelska som hon är när hon undervisar i teknik. Irenes förklaring till varför hon känner sig trygg i sin teknikundervisning syftar på hennes egna erfarenheter och hennes egen praktiska kunskap. 
De lärare som beskrev sig själva som osäkra i teknikundervisning, jämförde teknikundervisning med andra ämnen, och upplevde sig mer säkra i andra ämnen. Dessa lärare är inte utbildade i teknik, men har utbildning i de ämnen som de jämför med. Fiona berättade att hon upplever det svårt att veta om hon lägger sig på rätt nivå i sin undervisning eller ej.

Ämneskunskap - Lärarna i studien berättade på olika sätt om hur avsaknaden av ämneskunskap inom olika delar av teknikområdet ger upphov till lågt upplevd självförmåga. Det gäller både för lärare med och lärare utan teknikutbildning. Albert nämnde till exempel tekniska system och elektronik som områden han skulle vilja lära sig mer om, och Carl pratade om att han saknade en del praktiska kunskaper inom byggande och konstruktion. Brist på ämneskunskap kan leda till svårigheter med att välja rätt nivå, vilket Fiona gav exempel på när hon berättade om hur hon jobbar med de enkla maskinerna med sina elever.

Förberedelse - Att vara väl förberedd visade sig vara ett sätt för lärarna att hantera och kompensera för lågt upplevd självförmåga. Genom att läsa på, och att testa och prova hemma förberedde de sig inför mötet med eleverna. Diana beskrev att hon inte vill visa eleverna att hon inte behärskar allt inom teknikämnet. Jenny uttryckte att hon aldrig "skulle starta nåt och inte ha nån koll. Aldrig. Det finns inte". Även Ellen berättade om hur hon gör med de områden som hon inte riktigt kan hantera. De frågor som hon inte kan besvara diskuterar hon gärna tillsammans med sina elever, och hon ber ibland om att få återkomma nästa lektion, när hon hunnit läsa på och tagit reda på svar.

\section{Kontextberoende}

Kontextberoende är den andra delen av en lärares upplevda kontroll, och kontextberoende bygger på upplevelser av yttre kontroll i undervisningen. Resultatet visade på fyra underliggande teman som beskriver olika typer av kontextberoende som påverkar undervisningen.

Stöd av kollegor - Att kunna diskutera och utveckla sin teknikundervisning tillsammans med kollegor är något som beskrevs ha positiv effekt på undervisningen av lärare i den här studien. Flera lärare beskrev att de saknade denna typ av stöd på sina arbetsplatser. Det kunde dels bero på att det inte fanns tid att diskutera med tekniklärarkollegorna på skolan, men det kunde också bero på att det inte fanns någon att diskutera med. Belinda beskrev hur hon genom att diskutera kursplanen i teknik med andra tekniklärare kände sig mer säker och tog med sig nya kunskaper. Carl menade att det han efterfrågade mest var att få just stöd av kollegor: "det jag känner att jag har mest behov av det 
är ju att sitta med andra tekniklärare och prata rent om betyg och vad man väger in i bedömning."

Kursplan - Kursplanen i sig visade sig vara en kontextuell faktor som kan upplevas förenkla eller försvåra undervisningen. De lärare som beskrev kursplanen positivt menade att kursplanen är tydlig och enkel att förstå och följa, och bättre än kursplaner i andra ämnen. Harold, till exempel, sa att:

Tekniken är ändå det som känns, som är lättast att uppfylla, tycker vi, för den är inte så jättestor, omfattande och ganska enkel att förstå, kursplanerna och centrala innehållet. Så det är den jag känner mig mest bekväm i.

Andra uttryckte sig mer negativt och menade att kursplanen är svår att förstå. Albert efterfrågade lokala planer för teknikämnet för att hjälpa honom själv att förstå kursplanen och att kunna förklara den för eleverna. Ytterligare en negativ attityd till kursplanen kom fram i resultatet. Greg menade att han inte läste kursplanen och ansåg att det överlag läggs för mycket fokus på kursplaner och betygskriterier. Greg är en erfaren lärare, men hade bara undervisat $\mathrm{i}$ ämnet teknik några månader vid intervjutillfället. Han menade att han föredrog att se på lärande i ett bredare perspektiv än att fokusera på ämnets kursplan.

Resurser - Att teknikundervisningen påverkas negativt om det inte finns tillräckligt med materiella resurser, visade sig vara något som alla de 10 intervjuade lärarna var eniga om. Bristande resurser leder till att lärarna fick lägga sin kraft på andra saker än undervisning. Det var tre områden som tydligt framkom i studien, nämligen klassrummet, läromedel, samt material och ekonomiska resurser.

När det gäller klassrum så visade det sig att teknikundervisning sker i alla möjliga typer av klassrum, alla med olika fördelar och nackdelar. Det undervisades i teknik i slöjdsalar, bildsalar, NO-salar, hemklassrum, kombinerade NO- och tekniksalar och rena tekniksalar. Lärarna såg fördelar med att ha en renodlad tekniksal, eftersom det innebar att undervisningen underlättas. En del lärare var tvungna att gå mellan olika klassrum, vilket innebar att de måste bära med sig material och utrustning och samtidigt också upplevde svårigheter med förvaring. Salens utformning kunde också medföra begränsningar när det till exempel kommer till vilka material man kan jobba med. Harold menade att:

...man skulle behöva förnya grupprum, lokaler för att få plats, för att kunna ha det på plats, för att slippa släpa. Det är tråkigt! Det är inget roligt. 
Citatet visar hur klassrummet, som en kontextuell förutsättning, påverkar lärarens attityd.

I intervjuerna framkom också att man inte alltid hade läromedel (böcker) i teknik, vilket försvårade undervisningen. Belinda berättade att hon fick välja mellan att köpa in böcker eller konstruktionsmaterial till sina elever. En låg budget för ämnet leder till brist på material. Carl menade att lågt intresse hos lärarna kunde vara en förklaring till detta. Han ansåg att lärare med många ämnen i sina tjänster inte har haft så stort engagemang och intresse för teknikämnet, vilket lett till brist på resurser. Han tyckte att ingen riktigt tagit sig an ämnet.

När resurserna inte är tillräckliga så löser lärarna det problemet på olika sätt. Harold och Jenny, som båda använt Lego i undervisningen, har låtit eleverna arbeta i grupp för att få materialet att räcka till alla. Belinda lät eleverna ta med material hemifrån. Hon menade att bristen på material och avsaknaden av tekniksal hindrar undervisningen:

Man får ju uppfinna hjulet hela tiden. Det är ju inte direkt att det finns en massa material. Då skulle man ju vilja ha en labb-sal. Nu får man låna slöjdsalen. Och material, ja det är ju begränsat liksom.

Status - Lärarnas upplevelse av tid och uppmärksamhet för teknikämnet jämfört med andra ämnen kan kallas för ämnets status. Status ses då som upplevd yttre kontroll och därmed som en del av de kontextuella förutsättningarna. Denna typ av status tar sig uttryck på olika sätt inom en skolas organisation. När lärarna beskrev ämnets status gjorde de det mer utifrån lärares generella attityder än utifrån sin egen personliga uppfattning. Som nämnts tidigare så ansåg lärarna i studien generellt att teknik var ett viktigt ämne, men det beskrevs samtidigt som ett ämne i skuggan av andra ämnen och som ett ämne med lägre status än andra ämnen. Detta visade sig till exempel vid möten. Så här beskrev Carl ämnets status:

Jo, alltså det är så att det [Teknikämnet] kommer lite i skymundan, så är det ju. Dom andra lärarna som har teknik har alla NO och alla matte. Ibland är det så att det ska vara teknikträffar, eller man ska prata om teknik, men då blir det att man behandlar NO eller man behandlar matte istället [...] Det är synd. [...] [Tekniken] får ju inte lika mycket konferenstid som de andra ämnena.

Både Belinda och Carl lyfte avsaknaden av nationella prov som en anledning till att ämnet har låg status. NO-ämnena och matematiken, som har nationella prov, prioriterades istället. 
Kapitel 6

Diana var tydlig med att man på hennes skola behandlar alla ämnen lika, och att alla ämnen har samma status. Samtidigt berättade hon att:

I årskurs nio har dom nationella prov. Då är det mycket lättare för dem att inte ha så mycket teori som i alla andra ämnen, de bara kommer till lektionen och pysslar med saker och ting. Och så blir det nåt studiebesök, nån inlämningsuppgift osv. På så sätt belastar vi inte eleverna i slutet av läsåret, så har vi planerat all teknik i slutet av läsåret, maj till juni.

Citatet kan tolkas som att man trots allt ser på teknik på ett annat sätt än NO, att teknik anses vara en mindre belastning för eleverna. 
Kapitel 7

\section{Diskussion}

Forskningsfrågorna i studie 1 och studie 2 ligger nära varandra, medan metoderna skiljer sig åt desto mer. Den kvantitativa metoden i studie 1 och den kvalitativa metoden i studie 2 ger resultat av två olika typer, men har den gemensamma utgångspunkten - tekniklärares attityd - i fokus.

\section{Artikel 1}

Resultatet i artikel 1 visar på både bredd och komplexitet inom undervisning och utbildning, och speciellt när det gäller attityder.

Den första forskningsfrågan; Vad har svenska tekniklärare för attityder till teknikämnet och undervisningen?, besvaras genom resultatet från de två första analysmetoderna; faktoranalys och klusteranalys. Faktoranalysen ger oss fyra dimensioner av attityd. Klusteranalysen ger sedan en bild av skillnaden mellan olika lärare, med utgångspunkt i de fyra attityddimensionerna. De fyra dimensionerna av attityd kan knytas ihop med attitydmodellen som används som teoretisk utgångspunkt i denna licentiatuppsats.

Attityddimensionen Teknikundervisning är viktigt, kopplas till komponenten cognitive beliefs. Dimensionerna Förutsättningarna för teknikundervisning är goda och Kursplanen är i fokus för teknikundervisningen kopplas båda till komponenten perceived control (kontextberoende, yttre kontroll) och den fjärde och sista dimensionen $L \ddot{a}$ raren har intresse, kunskap och självförtroende beskrivs i artikeln med koppling till komponenten affective states. Artikel 2 har gett ett fördjupat perspektiv på begreppet perceived control, och i ljuset av resultaten från artikel 2, kan den fjärde attityddimensionen tolkas och kopplas samman med både perceived control och affective states. När skriftliga enkäter används så finns det alltid utrymme för tolkningar. Vissa frågor kunde säkert uppfattas på flera sätt, och vi vet därmed inte exakt hur lärarna som svarade på enkäten tolkade frågorna. Tittar man på de påståenden som ligger till grund för den fjärde attityddimensionen så är de kopplade både till self-efficacy (t.ex. betydelsen av eget intresse/kunskap för undervisningen i teknik), alltså en del av perceived control, och affective states (t.ex. "Jag brinner för ämnet teknik"), som mer renodlat innebär känslor.

Att bestämma antalet kluster är den mest kritiska delen av en klusteranalys, och antalet kluster bör, förutom att bestämmas med hjälp av statistiska metoder, också kontrolleras genom en rimlighets- 
bedömning (Hair et al., 2010), med andra ord en form av validering. I det här fallet kan utfallet med tre kluster anses rimligt då de tre klustren kan beskrivas och förklaras på ett meningsfullt sätt utifrån de data som bygger upp klustren. Resultatet kan också sättas i relation till andra studier och beprövad erfarenhet. Bilden av lärare med olika grad av positiva eller negativa attityder till undervisning bekräftas till exempel av Skolinspektionen (2014), och vidare, att lärare kan ha olika attityd till olika delar av ett ämne de undervisar i beskrivs av Holroyd and Harlen (1996).

Då flera av de variabler som testas i steg tre visar sig ha effekt som prediktorer, finns också olika möjliga förklaringar till lärares attityder. Högst effekt har de variabler som är kopplade till lärarens bakgrund och de som är kopplade till förutsättningar på skolan. Allra tydligast är att lärare som är behöriga, alltså har en lärarutbildning i teknik, med mycket hög sannolikhet tillhör den positiva gruppen. Att utbildade lärare är viktiga och har betydelse för eleverna och för ämnesutveckling har tidigare visats av till exempel Hartell et al. (2015), Mattsson (2005) och Jones, Buntting, and Vries (2013). Denna licentiatuppsats bidrar till att ytterligare beskriva vilken betydelse utbildning har, i detta fall för lärarna själva, och hur utbildning kan leda till bättre attityder till teknikundervisning hos lärare.

Det är viktigt att vara medveten om att resultaten i sig inte säger något om vad som är orsak och verkan. Det skulle också kunna vara så att lärare som har positiv attityd till teknikundervisning med större sannolikhet utbildar sig inom teknikämnet. Vi kan då ta hjälp av tidigare forskning för att tolka och förstå våra resultat. Tidigare studier visar att både fortbildning och utbildning påverkar lärares teknikundervisning på ett positivt sätt (t.ex. Bjurulf, 2008; Jones \& Carr, 1992). Med denna studie bygger vi vidare på kunskapen om betydelsen av utbildning hos lärare, och visar på att utbildning och fortbildning också kan ha betydelse för tekniklärares attityder. Resultatet blir än mer intressant i ljuset av att de variabler som är av stor betydelse, som utbildning, också är variabler som är möjliga att påverka.

Statistik från Skolverket (SiRiS, 2017) visar att teknikämnet är ett av ämnena med lägst andel behöriga lärare. Behovet av utbildade lärare har påtalats länge, ända sedan ämnet blev obligatoriskt på 1980-talet och en stor andel undervisande lärare saknade ämnesbehörighet (Elgström \& Riis, 1990). Det möjliga sambandet mellan utbildning och attityd gör problemet med outbildade tekniklärare ännu större. Lärare med positiv attityd kommer troligtvis att smitta av sig på eleverna vilket i sin tur kan få effekt för eleverna på olika sätt. Till exempel när det kommer till framtida studie- och yrkesval, något som med jämna mellanrum lyfts i den svenska samhällsdebatten. 
Inom teknikdidaktisk forskning har intresse för teknikämnet hos elever, med fokus på genus, studerats (t.ex. Svenningsson et al., 2018). Däremot har inte intresse- och attitydskillnader mellan män och kvinnor studerats hos tekniklärare på samma sätt. Resultatet i denna studie visar att kön är en prediktor för det blandade klustret, där kvinnor med större sannolikhet tillhör den grupp med blandade attityder än vad män gör. För de andra två grupperna är inte kön en prediktor. Skillnader i attityd mellan manliga och kvinnliga lärare är något som skulle vara intressant att undersöka djupare. En tidigare studie (Holroyd \& Harlen, 1996) påvisar ett liknande resultat, där män visade sig ha bättre självförtroende än kvinnor i de flesta avseenden gällande undervisning i teknik och naturvetenskap. Resultatet kan tolkas som att kvinnor kan behöva mer stöttning än män. Likaså kan våra resultat tolkas som att äldre lärare och lärare som undervisar i årskurs 4-9 har ett större behov av stöttning i ämnet, men inget av detta har undersökts närmare.

Resultatet visar att också skolkontexten har en inverkan på lärares attityder till teknik. Inom den teknikdidaktiska forskningen finns sedan tidigare inte så mycket skrivet inom detta område, men ett exempel är Andersson (1988). I min delstudie 1 visas att de kontextberoende variablerna med störst betydelse är att ha ett fastställt antal timmar till teknikundervisning och att ha en övergripande plan för ämnet. De lärare i studien som inte vet om det finns en plan för teknikämnet på deras skola eller inte, har med hög sannolikhet negativ attityd. Dessa båda variabler visar på att det är viktigt att skolan ger ämnet tid (undervisningstimmar) och utrymme (planering) för att på så sätt öka sannolikheten för positiva attityder hos lärarna. Även här kan man fundera över orsak och verkan, det är mycket möjligt att lärare med positiv attityd jobbar för att införa planering och tid för ämnet. Samtidigt kan man tänka sig att en lärare med negativ inställning till teknik antagligen kommer lägga mindre tid på teknik om skolan inte har tid och plats för tekniken, än vad han eller hon skulle gjort om skolan hade haft det.

De variabler som har mest betydelse i studien är de som enklast kan påverkas. Däremot är det inte enbart lärarna själva som kan påverka dessa variabler. Utbildning, fortbildning och hur man förhåller sig till teknikämnet på skolan genom att ge ämnet tid och ha en plan, är områden där ansvaret ligger hos staten, hos huvudmän och hos skolledare. Även om en lärare själv väljer att läsa in behörighet $\mathrm{i}$ ett ämne så ligger möjligheten att skapa goda förutsättningar för detta inte främst hos den enskilda läraren. Det är alltså svårt för lärarna själva att skapa en bättre situation och därmed möjliggöra mer positiva attityder. 


\section{Artikel 2}

Resultatet i licentiatuppsatsens andra artikel bidrar till en ökad kunskap om tekniklärares attityder och en utveckling av attitydmodellen (van Aalderen-Smeets et al., 2012), genom att underkategorierna i komponenten Perceived control utvecklats och anpassats för en teknikdidaktisk kontext. Perceived control visar sig vara centralt för tekniklärare och påverkar deras undervisning. Studien resulterar i tre underteman av upplevd inre kontroll, Self-efficacy: (1) Erfarenhet, utbildning och intresse, (2) Ämneskunskap och (3) Förberedelse, vilka alla tre innehåller varianter av hög eller låg Self-efficacy. Den upplevda yttre kontrollen, Context dependency, beskrivs med fyra underteman: (1) Stöd av kollegor, (2) Kursplan, (3) Resurser och (4) Status.

De två aspekterna av Perceived control som utvecklats i denna studie, bidrar till förståelsen av lärarnas attityder till teknikundervisning. De underteman som presenteras, beskrivs som fristående för att lättare kunna påvisas och diskuteras, men i verkligheten är de antagligen inte så tydligt separerade, utan kan förekomma samtidigt. Det är också möjligt att det finns ytterligare underteman som inte framkommit.

Fokus i studien är främst att måla upp den kollektiva bilden, och ett mindre fokus läggs på att beskriva var och en av de 10 deltagande lärarna separat. Sammantaget så upplevdes de 10 lärarna ha en generellt positiv attityd till teknikämnet. Eftersom alla 10 dessutom deltog frivilligt, så ligger det nära till hands att tro att dessa 10 är något mer positiva till teknikämnet än tekniklärare i allmänhet. En negativ tekniklärare tackar med stor sannolikhet nej till en intervju. Den sammantaget positiva inställningen syns till exempel i hur de utrycker sitt gillande till att vara tekniklärare och hur de beskriver ämnet som ett viktigt ämne. Jämför man med resultaten i artikel 1 så skulle dessa lärare alltså troligtvis ha höga värden i den första attityddimensionen "Teknik är viktigt”. Däremot, när det kommer till perceived control, som studeras närmare i denna delstudie, framkommer en mer negativ attityd.

\section{Self-efficacy}

Ett generellt resultat i denna studie är att self-efficacy hos lärarna varierar, dels mellan olika individer, men också för en och samma individ inom olika delar av teknikundervisningen. Tidigare forskning visar på hur hög self-efficacy hos lärare ger positiva effekter på undervisningen när det t.ex. gäller elevernas prestationer (Caprara, Barbaranelli, Steca, \& Malone, 2006; Tschannen-Moran et al., 1998) och kvaliteten på hur en lärare ger instruktioner (Holzberger, Philipp, \& Kunter, 2013). Som visats i denna delstudie så beror graden av self-efficacy hos lärare på 
omständigheter som erfarenhet, utbildning, intresse, ämnesinnehåll, tid för förberedelse eller själva undervisningssituationen. Graden av self-efficacy varierar för en och samma lärare. Därutöver kan man också se att lärarna utvecklar strategier för att hantera sin osäkerhet och sin låga self-efficacy, genom att läsa på, öva hemma och att vara väl förberedda. Detta tar givetvis tid, så det begränsar ju vad läraren kommer att välja att undervisa om. Resultatet visar vidare på att hög selfefficacy verkar vara kopplat till lärarutbildning i teknik, men också till erfarenhet och personligt intresse för teknik.

Resultatet visar att det finns vissa skillnader mellan lärare med och utan lärarutbildning i teknik. De mest osäkra av de 10 deltagarna finns i gruppen utan lärarutbildning i teknik. Det kan vi se i uttalanden om att lärarna känner sig mer säkra i andra ämnen än teknik, som de i motsats till teknik är utbildade i. Välutbildade lärare är av stor vikt när det gäller utveckling av teknikämnet (Jones, Buntting, \& de Vries, 2013), intresset hos elever (Mattsson, 2005) och bedömning (Hartell et al., 2015). Delstudie 1 visar på att det är mycket högre sannolikhet att ha en positiv attityd till teknik och teknikämnet, om man är utbildad tekniklärare, eller har deltagit i kompetensutveckling. En studie av lärare inom STEM (Science Technology Engineering Mathematics) (Bell, 2016) visar att lärarens kunskap och förståelse är kopplad till effektivitet i klassrummet. I intervjuerna ser vi att det är lärarnas personliga teknikintresse, deras utbildning och deras egen vardag som av dem själva beskrivs vara källan till god self-efficacy, något som påminner om det välutvecklade personliga intresse för teknik som diskuteras av bland andra Svenningsson et al. (2018) och Hidi and Renninger (2006).

Oavsett om lärare har en lärarutbildning i teknik eller ej så kan de ha olika grad av self-efficacy när det gäller teknikundervisningens olika delar. En lärare gör ofta mer av det som han eller hon upplever sig säker på, och mindre av de områden som upplevs osäkra (Holroyd \& Harlen, 1996). Diana ger ett exempel på detta när hon beskriver hur hon försöker hålla teknikeleverna inom den del av teknikämnet där hon upplever kontroll och säkerhet, och inte ger dem chans att ställa frågor om andra områden. På samma sätt visar det sig att STEM-lärare undviker risktaganden och begränsar bredden i undervisningen om de känner sig osäkra, enligt en studie av Bell (2016).

\section{Context dependency}

I denna studie framkommer ett antal externa omständigheter som har betydelse för undervisningen, som en del av attitydaspekten perceived 
control. Redan på 1980-talet, när teknikämnet nyligen blivit obligatoriskt, påvisades hur kontextuella faktorer upplevdes vara försvårande för teknikundervisningen (Andersson, 1988). Då var få tekniklärare utbildade i ämnet, och likaså saknade många lärare erfarenhet av ämnet, speciellt lärare som undervisade lägre åldrar (årskurs 1-6). Det som saknades då var tid, läroböcker, material och tekniksalar. Bristen på material och bristen på funktionella klassrum framkom även i en studie av Blomdahl (2007), där ramfaktorer i teknik undersöktes. I min studie visar sig lärarna uttrycka ungefär samma problem.

En av de externa faktorer som framkommer i resultatet är stöd av kollegor. Lärarna anser detta vara viktigt och något som saknades i flera fall. Behovet av stöd från kollegor har också visats i en australiensisk studie, där implementeringen av mekatronik i undervisningen har studerats (Nicholas \& Ng, 2012). Förutom stöd från kollegor framkom också behovet av tid för organisation och planering i den studien.

Ett intressant resultat är att utbildade tekniklärare verkar anse att kursplanen i teknik är mer lättförståelig och lättolkad, än vad lärare utan lärarutbildning i teknik tycker. De anser också att kursplanen har en positiv påverkan på undervisningen, medan lärarna utan utbildning i teknik anser sig ha svårigheter med att förstå kursplanen och anpassa sig till den. Sammantaget så kan man dock konstatera att kursplanen för vissa lärare är ett dokument som hjälper dem i undervisningen, medan andra anser det vara ett dokument som är svårt att förstå och hantera. Förekomsten av olika attityder, både positiva och negativa, har också erfarits på Nya Zeeland i samband med införandet av teknikämnet (Jones et al., 2004). Där fanns lärare som ansåg att kursplanen i teknik var lätt att använda, medan andra ville förändra den och göra den lättare att förstå. I en svensk studie (Mattsson, 2005) jämförs lärare med formell lärarutbildning i skolämnet teknik med lärare utan lärarutbildning i teknik. De tekniklärarutbildade hade kursplanen som utgångspunkt i undervisningen, medan de utan teknikutbildning mer gick på intuition.

Bjurulf (2008) diskuterar klassrummets betydelse för innehållet i teknikundervisningen. Klassrummet och vad som finns där i form av utrustning signalerar vilken typ av utbildning och undervisning som ska genomföras där. Om teknikundervisning äger rum i en lektionssal utformad för NO-undervisning, är en möjlig konsekvens att teknikämnet uppfattas som mindre viktigt. Resultaten i artikel två visar att olika resurser, som klassrumssituationen, läroböcker, material och ekonomiska resurser, påverkar undervisningen direkt, på ett praktiskt sätt, främst genom att begränsa lärarna. Det visas till exempel i Jennys och Harolds beskrivningar av hur de använder Lego i undervisningen, då tillgången på Lego avgör hur många elever som făr jobba tillsammans. 
Det kan också bli som Diana beskriver, att hon begränsas i valet av material. På grund av klassrummets utformning kan hon inte använda det konstruktionsmaterial hon vill. Bristen på böcker, material och utrymme för förvaring är villkor som påverkat attityder hos läraren även i tidigare forskning både i Sverige (Blomdahl, 2007) och på Nya Zeeland (Jones et al., 2004), men i vår studie kan vi också se vad bristen på resurser kan leda till. Lärarna beskriver på olika sätt hur de måste lägga tid och energi på att lösa praktiska problem som uppstår. Det kan vara att förflytta material, hitta material eller förvara material till teknikundervisningen. När teknikundervisningen bedrivs i elevernas hemklassrum finns inte plats för att förvara material mellan lektionerna. Bristen på resurser och de svårigheter det medför, bidrar till att lärare făr en negativ attityd till teknikundervisningen.

Teknik har ansetts ha lägre status än naturvetenskap, vilket till exempel visas i en studie av Osborne et al. (2003). I Sverige har ju teknikämnet starka kopplingar till NO-ämnena. Innan teknik blev ett eget ämne så var det en del av NO-ämnena (Lgr 80) (Skolöverstyrelsen, 1980) och denna koppling har sedan följt ämnet. Teknikämnet delar timplaneutrymme med de tre NO-ämnena kemi, fysik och biologi. Likaså är det vanligt att en och samma lärare undervisar i alla fyra ämnen. När lärarna i intervjuerna talar om status, är det därför nära till hands att utgå ifrån att man ofta jämför teknikämnet med de tre NOämnena. Ingen av de intervjuade lärarna har direkt uttryckt att teknikämnet har en annan status än andra ämnen. Ändå finns det en tråd igenom intervjuerna om ämnets ställning, där vi kan se att teknikämnet ibland upplevs bli behandlat annorlunda av lärare och skolledning. Några lärare nämner att man sett hur teknikämnet har en sämre ställning på andra skolor, och att det rent generellt är så, även om det inte stämmer med hur det ser ut på deras egen skola. Dianas exempel är intressant, när hon först beskriver att alla ämnen på hennes skola behandlas lika, och i nästa mening beskriver hur man valt att lägga in teknik sist på läsåret, när eleverna är lite trötta och de tyngre ämnena är avklarade. Ett liknande resonemang har visats i en brittisk studie, där teknikundervisningen sågs som en belöning i slutet av en läsperiod (Bell et al., 2016).

I Sverige har vi inga nationella prov i teknik, men det finns det däremot i de tre NO-ämnena. Det är möjligt att detta är en bidragande orsak till att teknikämnet ibland inte har samma ställning som NOämnena på vissa skolor. Resultaten i teknik syns och jämförs inte på samma sätt som resultaten i kemi, fysik och biologi, bland annat på grund av avsaknaden av nationella prov. 


\section{Övergripande slutsatser och implikationer}

Fokus i denna licentiatuppsats är attityder. Det kan vara viktigt att påpeka att attityder bara är en beståndsdel bland många andra som har betydelse för undervisning och lärande. Likaså är inte den valda attitydmodellen den enda möjliga modellen att använda för att beskriva attityder, utan en modell som valts för att den ansågs vara lämplig i sammanhanget. Det är möjligt att en annan modell hade gett en delvis annan bild av attityder hos tekniklärare.

Sammanfattningsvis kan det vetenskapliga bidraget formuleras i tre punkter:

1. En utveckling av modellen (van Aalderen-Smeets \& Walma van der Molen, 2013; van Aalderen-Smeets et al., 2012), vilket innebär att den tredje aspekten av attityd i modellen, Upplevd kontroll, har utvecklats med underkategorier med utgångspunkt i tekniklärares upplevelser av teknikundervisning. Denna del av modellen, som är lärarspecifik, kan nu användas och testas i ytterligare studier.

2. En ökad förståelse av tekniklärares attityder. Bilden av tekniklärares attityder har i denna licentiatuppsats fördjupats och breddats. Studiernas resultat kan till exempel användas i lärarutbildningen. Resultaten ger implikationer för hur man i lärarutbildningen kan arbeta för att skapa goda möjligheter till positiva attityder hos de blivande lärarna som ska undervisa i teknik. Detta kan göras genom att medvetandegöra om resultaten i denna studie, att låta studenterna få ta del av vad som påverkar lärares attityder och bli medvetna om att det finns skillnader i attityder hos lärare. Genom att till exempel låta lärarstudenterna arbeta med övergripande planering av teknikundervisning för att få en helhetsbild och röd tråd så kan man ge dem en god grund inför yrkeslivet som tekniklärare. Likaså kan man i lärarutbildningen trycka på fördelarna av att ha tid tillsammans med andra lärare för planering och diskussion, alltså att påvisa att teknik är ett ämne där stöd från kollegor är extra viktigt.

3. En utgångspunkt för vidare forskning. Studiens resultat ger uppslag till vidare forskning kring tekniklärare. Till exempel så skulle modellens (van Aalderen-Smeets \& Walma van der Molen, 2013; van Aalderen-Smeets et al., 2012) två andra aspekter av attityd, Kognitiva uppfattningar och Affektiva tillstånd, också kunna undersökas djupare för att få en bättre bild av tekniklärarnas attityder. En tråd att följa upp skulle 
också kunna vara att studera hur lärares attityd påverkar elevers attityd och kanske också val i framtiden. Resultaten i studierna visar att det ofta inte är lärarna själv som kan påverka de faktorer som har betydelse, det är beslutsfattare och skolledare som äger frågan - detta skulle också kunna undersökas vidare i framtida forskning. Hur tänker beslutsfattarekring teknikundervisning, jämfört med andra ämnen? Till sist är ytterligare ett spår intressant att följa upp. I studierna framkommer att det finns lärare som väljer att hålla sin undervisning i teknik inom det område där de själva känner sig trygga och säkra. Hur påverkar detta elevernas teknikundervisning? Vilket ämnesinnehåll innebär det att de får möta?

\section{Implikationer för yrkesverksamheten}

De båda delstudierna beskriver attityd ur olika perspektiv, och genom att lägga samman resultaten från båda studierna finns också möjlighet att försöka hitta vägar framåt, för att hitta sätt att förbättra attityder hos tekniklärare och skapa bättre förutsättningar för teknikundervisning. En gemensam faktor som identifierats är tid. Tid visar sig vara en faktor som påverkar lärares attityd till teknikundervisning, och kan betraktas ur tre olika synvinklar.

\section{Låt teknikundervisning få tid}

Sammantaget kan man från artikel 1 konstatera att lärare som arbetar på skolor där ämnet får synas och ta plats, tenderar att med större sannolikhet ha en positiv attityd till teknikundervisningen. Det är lärare som arbetar på skolor där man har en långsiktig och övergripande plan för teknikämnet, samt lärare på skolor med ett bestämt antal timmar för teknikundervisning som är mer positiva i sin attityd. Att ha en övergripande plan och att ha timmar avsatt för teknik är två kontextuella förutsättningar som relativt enkelt kan följas upp på varje enskild skola av respektive skolledare. Det handlar om att låta teknikämnet få samma möjligheter till undervisningstid som andra ämnen och att ta sig tid att skapa riktlinjer och målsättningar för ämnet. Med andra ord kan man säga att trots att teknik varit obligatoriskt sedan Lgr8o och ett eget ämne sedan Lpo94 så syns det inte i samma utsträckning som andra ämnen på vissa skolor. Skolinspektionens granskning av teknikämnet (Skolinspektionen, 2014) visar på samma dilemma, att ämnet inte ges 
det utrymme som andra ämnen får på skolorna. En liknande upplevelse bekräftas av de intervjuade lärarna i artikel 2. Ett exempel är när Carl beskriver att ämnet hamnar i skymundan. Lärarna i artikel 2 upplever att teknikämnet generellt har lägre status än andra ämnen, speciellt i jämförelse med NO-ämnena som teknikämnet delar timplaneutrymme med. För lite tid till teknikundervisning kan leda till att eleverna inte får den undervisning de har rätt till.

I skrivande stund, december 2017, är förändringar på väg att implementeras när det gäller teknikundervisning i svensk grundskola. Nyligen kom ett beslut om förändring i Skollagen (SFS 2017:1236) vilket medför att timplanen för grundskolan skrivs om. Teknik, kemi, fysik och biolog kommer få 200 undervisningstimmar per ämne, istället för att som det nu är, att ämnena tillsammans har 800 timmar. Av dessa 800 timmar har teknikämnet ofta fått mindre än 200 timmar, ibland till och med färre än 100 timmar (Skolinspektionen, 2014). Den nya timplanen gäller från $1 / 7$ 2018. Att få 200 timmar per ämne är ett steg i rätt riktning, utifrån de resultat vi visat på i artikel 1. Där visas ju att "att ha ett fast antal timmar avsatta för teknikundervisning" predikterar positiv attityd hos lärare.

\section{Låt tekniklärarna få tid att mötas}

I detta fall handlar det inte bara om att låta teknikämnet få tid i undervisningen, lärarna själva behöver också tid för att tillsammans mötas kring ämnet. Stöd av kollegor visar sig vara en del av en lärares upplevda yttre kontroll, som kan underlätta eller försvåra teknikundervisningen, beroende på hur förutsättningarna ser ut. Resultaten påvisar att lärare som inte har tid att träffa sina kollegor, eller som saknar kollegor i teknik, anser sig behöva detta, och det påverkar attityden. På samma sätt upplever lärare som har tid och möjlighet att träffa sina kollegor, för att samtala om och planera för teknikundervisning, att det är något som underlättar och stärker deras undervisning. Stöd från kollegor gör lärare mer säkra och kan påverka attityden positivt. Lärarna i artikel 2 vill prata om bedömning, utbyta idéer och erfarenheter och diskutera kursplanen och hur man ska tolka den. Att inte tid för dessa möten finns förklaras med att andra ämnen prioriteras högre av skolledaren eller av andra lärare. Även tid att mötas kan ses som en kontextuell förutsättning, och något som likaså relativt enkelt kan ges förutsättningar till av varje enskild skolledare, genom att planera för möten och avsätta tid för ämnesträffar på ett rättvist sätt. 


\section{Låt tekniklärarna få tid för utbildning och kompetens- utveckling}

Den tredje aspekten av tid handlar om att avsätta tid och resurser för att utbilda och kompetensutveckla lärare i teknik. Studierna visar att utbildning och kompetensutveckling har stor betydelse för attityden hos lärare. Utbildade tekniklärare är med högre sannolikhet positivt inställda till teknikundervisning. Utbildade tekniklärare visar också ett större intresse för teknikämnet. I artikel 1 är behörigheten, alltså lärarutbildning som gett behörighet i teknik, den enskilt starkaste prediktorn för att bli klassificerad i den positiva gruppen. Detta bekräftas i artikel 2, där de utbildade lärarna upplever högre self-efficay överlag. Tidigare forskning visar att upplevd självförmåga har betydelse för undervisningen och därmed elevernas resultat. Teknikämnet är, enligt Skolverkets statistik, ett av de ämnen med lägst andel undervisande lärare som har legitimation och behörighet i sitt ämne (SiRiS, 2017). Här finns alltså ett problem att lösa. Skolledare och huvudmän bör se till att fler lärare blir behöriga att undervisa i teknik, och att fler får kompetensutveckling. Med tanke på teknikämnets karaktär och förändringstakt bör kompetensutveckling vara ett återkommande inslag. De exempel som kommer fram i studie 2, där lärarna beskriver att de vill vara väl förberedda innan de undervisar, visar på ett behov av kompetensutveckling. Behovet av utbildning och kompetensutveckling är generellt högre inom teknikämnet än andra ämnen, eftersom andelen lärare med utbildning i teknik är låg, men också eftersom ämnet har en kort tradition och föränderlig karaktär i takt med den snabba teknikutvecklingen.

Den 1/7 2018, börjar också en reviderad kursplan i teknik att gälla. Den innehåller nya skrivningar om digital kompetens. De lärare som känner sig osäkra och vill förbereda sig hemma innan undervisning i klassrummet får en stor börda på sina axlar. Det är sannolikt så att det finns osäkra lärare som kommer undvika dessa nya skrivelser på grund av att de inte kommer har tid för förberedelser och fortbildning. Att ge lärare tid för utbildning och kompetensutveckling är inte en lika enkel att åtgärd som att ge tid för ämnet och tid för ämnesmöten, men den är minst lika angelägen. En tillbakablick visar att behovet av kompetensutveckling och utbildning har följt ämnet ända sedan 1980-talet (Andersson, 1988; Elgström \& Riis, 1990). 
Kapitel 8

\section{Referenser}

Ajzen, I. (2001). Nature and operation of attitudes. Annual review of psychology, 52(1), 27-58.

Ajzen, I. (2005). Attitudes, personality and behavior (2 ed.): Maidenhead: Open University.

Albarracín, D., Johnson, B. T., Zanna, M. P., \& Kumkale, G. T. (2005). Attitudes: Introduction and scope. The handbook of attitudes, 3-19.

Andersson, Y. (1988). Teknikämnet på grundskolans mellanstadium: Department of Education and Psychology, Linköping University.

Asma, L., van der Molen, J. W., \& van Aalderen-Smeets, S. (2011). Primary teachers' attitudes towards science and technology Professional Development for Primary Teachers in Science and Technology (pp. 89-105): Springer.

Bagozzi, R. P., \& Burnkrant, R. E. (1985). Attitude Organization and the Attitude-Behavior Relation: A reply to Dillon and Kumar. Journal of personality and social psychology, 49(1), 47-57.

Bandura, A. (1997). Self-efficacy : the exercise of control: Basingstoke : W. H. Freeman.

Bell, D. (2016). The Reality of STEM Education, Design and Technology Teachers' Perceptions: A Phenomenographic Study. International Journal of Technology and Design Education, 26(1), 61-79.

Bell, D., Martin, M., Woff, D., \& McLain, M. (2016). Primary Design and Technology: Perceptions and practice Paper presented at the PATT-32.

Bjurulf, V. (2008). Teknikämnets gestaltningar: en studie av lärares arbete med skolämnet teknik: Karlstad: Estetisk-filosofiska fakulteten, Pedagogiskt arbete, Karlstads universitet.

Bjurulf, V. (2013). Teknikdidaktik. Lund: Studentlitteratur.

Blomdahl, E. (2007). Teknik i skolan: en studie av teknikundervisning för yngre skolbarn. Stockholm: HLS förlag.

Braun, V., \& Clarke, V. (2006). Using thematic analysis in psychology. Qualitative research in psychology, 3(2), 77-101.

Breckler, S. J. (1984). Empirical validation of affect, behavior, and cognition as distinct components of attitude. Journal of personality and social psychology, 47(6), 1191.

Caprara, G. V., Barbaranelli, C., Steca, P., \& Malone, P. S. (2006). Teachers' self-efficacy beliefs as determinants of job satisfaction 
and students' academic achievement: A study at the school level. Journal of school psychology, 44(6), 473-490.

Carlgren, I. (2013). Hurusom teknik kom att skiljas från naturvetenskap i "Skola för bildning". In J. Hallström \& C. Klasander (Eds.), Ginners teknikdidaktiska handbok: några teser om teknik, skola och samhälle : [The Ginner handbook of technology education : some theses about technology, school and society] (pp. 115-127). Norrköping: Centrum för tekniken i skolan (CETIS), Linköpings universitet.

CETIS. (1998). Hur står det till med tekniken i skolan? [Internt material, opublicerat].

Clatworthy, J., Buick, D., Hankins, M., Weinman, J., \& Horne, R. (2005). The use and reporting of cluster analysis in health psychology: A review. British Journal Of Health Psychology, $10(3), 329-358$.

De Vries, M. J. (1991). What Do Students in Dutch Technology Teacher Programmes Think of Their Subject? Research in Science and Technological Education, 9(2), 173-180.

Dillon, W. R., \& Kumar, A. (1985). Attitude organization and the attitude-behavior relation: A critique of Bagozzi and Burnkrant's reanalysis of Fishbein and Ajzen. Journal of personality and social psychology, 49(1), 33-46.

Elgström, O., \& Riis, U. (1990). Läroplansprocesser och förhandlingsdynamik : exemplet obligatorisk teknik $i$ grundskolan: Linköping : Tema, Univ., 1990 ; 1 . uppl.

Field, A. (2009). Discovering statistics using SPSS: (and sex and drugs and rock ' $n$ ' roll) (3d ed.): London: SAGE.

Hair, J. F., Black, W. C., Babin, B. J., \& Anderson, R. E. (2010). Multivariate data analysis : a global perspective (7th ed.). Upper Saddle River, N.J.: Pearson Education

Hallström, J., Hultén, M., \& Lövheim, D. (2014). The study of technology as a field of knowledge in general education: historical insights and methodological considerations from a Swedish case study, 1842-2010. International Journal of Technology and Design Education, 24(2), 121-139.

Hartell, E., Gumaelius, L., \& Svärdh, J. (2015). Investigating technology teachers' self-efficacy on assessment. International Journal of Technology \& Design Education, 25(3), 321-337. doi:10.1007/s10798-014-9285-9

Hedlin, M., \& Gunnarsson, G. (2014). Preschool student teachers, technology, and gender: positive expectations despite mixed experiences from their own school days. Early Child Development and Care, 184(12), 1948-1959. 
Hidi, S., \& Renninger, K. A. (2006). The four-phase model of interest development. Educational psychologist, 41(2), 111-127.

Holroyd, C., \& Harlen, W. (1996). Primary teachers' confidence about teaching science and technology. Research papers in education, 11(3), 323-335.

Holzberger, D., Philipp, A., \& Kunter, M. (2013). How teachers' selfefficacy is related to instructional quality: A longitudinal analysis. Journal of Educational Psychology, 105(3), 774.

Hultén, M. (2013). Teknik för alla. Efterkrigstidens skolreformer och det nya skolämnet Teknik. In J. Hallström, M. Hultén, \& D. Lövheim (Eds.), Teknik som kunskapsinnehåll $i$ svensk skola 1842-201O (pp. 169-214). Norrköping: Gidlunds förlag.

Johansson, C. (2010). Framgång i undervisningen: Skolinspektionen (Dnr 2010: 1284) Stockholm.

Jones, A., Buntting, C., \& de Vries, M. J. (2013). The Developing Field of Technology Education: A Review to Look Forward. International Journal of Technology and Design Education, 23(2), 191-212.

Jones, A., Buntting, C., \& Vries, M. (2013). The developing field of technology education: a review to look forward. International Journal of Technology \& Design Education, 23(2), 191-212. doi:10.1007/s10798-011-9174-4

Jones, A., \& Carr, M. (1992). Teacher's perceptions of technology education: Implications for curriculum innovation. Research in Science Education, 22(1), 230-239.

Jones, A., Harlow, A., \& Cowie, B. (2004). New Zealand Teachers' Experiences in Implementing the Technology Curriculum. International Journal of Technology and Design Education, 14(2), 101-119.

Korur, F., Vargas, R. V., \& Serrano, N. T. (2016). Attitude toward Science Teaching of Spanish and Turkish In-service Elementary Teachers: Multi-group Confirmatory Factor Analysis. Eurasia Journal of Mathematics, Science \& Technology Education, 12(2), 303-320.

Kvale, S., \& Brinkmann, S. (2014). Den kvalitativa forskningsintervjun (3rd ed.). Lund: Studentlitteratur.

Larsson, S. (2005). Om kvalitet i kvalitativa studier. Nordisk Pedagogik, 25(1), 16.

Lövheim, D. (2013). Teknikens gränser. Formering och positionering av grundskolans teknikämne 1975 - 2010. In J. Hallström, M. Hultén, \& D. Lövheim (Eds.), Teknik som kunskapsinnehåll $i$ svensk skola 1842-201O (pp. 215-250). Norrköping: Gidlunds förlag. 
Mattsson, G. (2005). Lärares teknikdidaktiska kompetens och dess betydelse för elevers teknikintresse. Nordina, o1(01), 31-42.

Mooi, E., \& Sarstedt, M. (2011). A concise guide to market research : the process, data, and methods using IBM SPSS statistics. Berlin: Springer.

Männikkö-Barbutiu, S. (2011). Developing Teaching in Technology From Isolation to Cooperation. In M. J. d. Vries (Ed.), Positioning Technology Education in the Curriculum (pp. 103117). Rotterdam: SensePublishers.

Nicholas, H., \& Ng, W. (2012). Factors influencing the uptake of a mechatronics curriculum initiative in five Australian secondary schools. International Journal of Technology and Design Education, 22(1), 65-90. doi:10.1007/s10798-010-9138-0

Nordlander, E. (2011). Vad tycker tekniklärarna? In S. O. Hansson, E. Nordlander, \& I.-B. Skogh (Eds.), Teknikutbildning för framtiden (pp. 90-102). Stockholm: Liber AB.

Nordlöf, C., Hallström, J., \& Höst, G. E. (2017). Self-efficacy or context dependency?: Exploring teachers' perceptions of and attitudes towards technology education. International Journal of Technology and Design Education, 1-19.

Nordlöf, C., Höst, G. E., \& Hallström, J. (2017). Swedish technology teachers' attitudes to their subject and its teaching. Research in Science \& Technological Education, 35(2), 195-214. doi:10.1080/02635143.2017.1295368

Norström, P. (2014). How technology teachers understand technological knowledge. International Journal of Technology \& Design Education, 24(1), 19-38.

Osborne, J., Simon, S., \& Collins, S. (2003). Attitudes towards Science: A Review of the Literature and Its Implications. International Journal of Science Education, 25(9), 1049-1079.

Pett, M. A., Lackey, N. R., \& Sullivan, J. J. (2003). Making sense of Factor Analyses. Thousand Oaks: SAGE Publications.

Raat, J. H., \& de Vries, M. (1986). What do girls and boys think of technology. Pupils' attitudes towards technology.

Riis, U. (2013). Teknik - mellan slöjd och naturvetenskap. In J. Hallström \& C. Klasander (Eds.), Ginners teknikdidaktiska handbok: några teser om teknik, skola och samhälle (pp. 100114). Norrköping: Centrum för tekniken i skolan (CETIS).

Robson, C. (2011). Real world research : a resource for users of social research methods in applied settings: Chichester : Wiley, 2011.

Rohaan, E., Taconis, R., \& Jochems, W. (2012). Analysing teacher knowledge for technology education in primary schools. 
International Journal of Technology \& Design Education, 22(3), 271-280.

Rosenberg, M. J., \& Hovland, C. I. (1960). Cognitive, affective, and behavioral components of attitudes. In C. I. Hovland \& M. J. Rosenberg (Eds.), Attitude organization and change (pp. 1-14). New Haven Yale university Press.

Shulman, L. S. (1986). Those Who Understand: Knowledge Growth in Teaching. Educational Researcher, 15(2), 4.

SiRiS. (2017). Kvalitet och resultat i skolan. Retrieved from http://siris.skolverket.se/siris/f?p=Siris:1:0

Sjöberg, S. (2013). Grundläggande tekniska förmågor. In J. Hallström \& C. Klasander (Eds.), Ginners teknikdidaktiska handbok: några teser om teknik, skola och samhälle : [The Ginner handbook of technology education : some theses about technology, school and society] (pp. 49-60). Norrköping: Centrum för tekniken i skolan (CETIS), Linköpings universitet.

Skolinspektionen. (2014). Teknik - gör det osynliga synligt (04). Retrieved from

Stockholm: http://www.skolinspektionen.se/Documents/publikationssok/g ranskningsrapporter/kvalitetsgranskningar/2014/teknik/kvalgr -teknik-slutrapport.pdf

Skolverket. (2000). Grundskolan: kursplaner och betygskriterier. Kommentarer. Stockholm: Skolverket.

Skolverket. (2006). Läroplan för det obligatoriska skolväsendet, förskoleklassen och fritidshemmet Lpo 94. Stockholm: Skolverket.

Skolverket. (2008). Grundskolans kursplaner och betygskriterier (Vol. 2:1). Stockholm.

Skolverket. (2011). Läroplan för grundskolan, förskoleklassen och fritidshemmet 2011. Stockholm: Skolverket.

Skolverket. (2013). Föreskrifter om ändring i skoverkets föreskrifter (SKOLFS 2011:35) om ansökan om legitimation för lärare och förskollärare m.m. (SKOLFS 2013:160).

Skolverket. (2014). Redovisning av uppdrag om hur stor del av undervisningen som bedrivs av behöriga lärare. Retrieved from http://www.skolverket.se/publikationer?id=3312

Skolverket. (2016, 2016-10-31). Legitimation. Retrieved from http://www.skolverket.se/kompetens-ochfortbildning/lararlegitimation/legitimation-1.237043

Skolverket. (2017). Siris Grundskolan - personalstatistik med behörighet - per ämne och kategori. Retrieved from http://siris.skolverket.se/reports/rwservlet?cmdkey=common $\underline{\text { \&notgeo }=\& p \text { verksamhetsar }=2015 \& p \text { omgang }=1 \& \text { report }=\text { pers }}$ 
Kapitel 8

onal amne2\&p skolkod=\&lankod=\&kommunkod=\&p hman= oo\&p niva $=S \& p$ amne $=\& p$ verksform $=11$

Skolöverstyrelsen. (1980). Läroplan för gundskolan, Lgr 8o, Allmän del. Stockholm.

Svenningsson, J., Hultén, M., \& Hallström, J. (2018). Understanding attitude measurement: exploring meaning and use of the PATT short questionnaire. International Journal of Technology and Design Education, 28(1), 67-83. doi:10.1007/s10798-016-9392$\mathrm{x}$

Teknikföretagen. (2012) Teknikämnet i träda; teknikföretagens och CETIS rapport om teknikundervisningen i grundskolan. Stockholm.

Tschannen-Moran, M., Hoy, A. W., \& Hoy, W. K. (1998). Teacher Efficacy: Its Meaning and Measure. Review of Educational Research, 68(2), 202-248.

van Aalderen-Smeets, S., \& Walma van der Molen, J. (2013). Measuring Primary Teachers' Attitudes Toward Teaching Science: Development of the Dimensions of Attitude Toward Science (DAS) Instrument. International Journal of Science Education, 35(4), 577-600.

van Aalderen-Smeets, S., Walma van der Molen, J., \& Asma, L. (2012). Primary Teachers' Attitudes toward Science: A New Theoretical Framework. Science Education, 96(1), 158-182.

Vetenskapsrådet, S. (2002). Forskningsetiska principer inom humanistisksamhällsvetenskaplig forskning: Elanders Gotab. http://www. vr. se/download/18.7 f7bb63a11eb5b697f3800012802/forskningsetiska_pri nciper_tf_2002.pdf. 


\section{Bilaga 1: Intervjuguide}

\begin{tabular}{|c|c|c|}
\hline Område & Huvudfrågor & $\begin{array}{l}\text { Exempel på fortsätt- } \\
\text { ningsfrågor }\end{array}$ \\
\hline Lärarens bakgrund & $\begin{array}{l}\text { Vad undervisar du i? } \\
\text { Berätta om din bak- } \\
\text { grund! }\end{array}$ & $\begin{array}{l}\text { Examen (utbildningar } \\
\text { och år, universitet) } \\
\text { Ålder? } \\
\text { Lärarleg.? } \\
\text { Teknik i din utbildning? } \\
\text { Andra arbeten/yrken? } \\
\text { Sätter du betyg i teknik? }\end{array}$ \\
\hline Identitet & $\begin{array}{l}\text { Hur beskriver du dig } \\
\text { själv som lärare? } \\
\text { Hur presenterar du } \\
\text { dig? }\end{array}$ & $\begin{array}{l}\text { Hur tror du att en } \\
\text { elev/kollega skulle besk- } \\
\text { riva dig? } \\
\text { Vilka ämnen står dig } \\
\text { närmast? }\end{array}$ \\
\hline Tekniksyn & $\begin{array}{l}\text { Vad är teknik? Be- } \\
\text { skriv vad teknik är för } \\
\text { dig. } \\
\text { Vad är inte teknik? } \\
\text { Var tror du att du har } \\
\text { fått din tekniksyn } \\
\text { ifrån? }\end{array}$ & $\begin{array}{l}\text { Hur beskriver du tek- } \\
\text { nikämnet för t.ex. en } \\
\text { elev eller en förälder? } \\
\text { Vad är viktigast att ele- } \\
\text { verna făr med sig från } \\
\text { teknikundervisningen i } \\
\text { grundskolan? } \\
\text { Vad lägger du tyngd- } \\
\text { punkt på i teknikunder- } \\
\text { visningen? Vad är vik- } \\
\text { tigast? } \\
\text { Svårt att hinna med allt } \\
\text { centralt innehåll? Om du } \\
\text { inte skulle hinna med } \\
\text { allt, vad skulle du välja } \\
\text { bort? }\end{array}$ \\
\hline Varför teknik & $\begin{array}{l}\text { Har du valt att un- } \\
\text { dervisa i teknik eller } \\
\text { har du blivit tilldelad } \\
\text { ämnet? Berätta! }\end{array}$ & $\begin{array}{l}\text { Hur länge och hur det } \\
\text { varit tidigare? } \\
\text { Vilka ämnen undervisar } \\
\text { du helst i? }\end{array}$ \\
\hline
\end{tabular}




\begin{tabular}{|c|c|c|}
\hline $\begin{array}{l}\text { Teknik jämfört med } \\
\text { andra ämnen }\end{array}$ & $\begin{array}{l}\text { Beskriv hur du tycker } \\
\text { teknikämnet "be- } \\
\text { handlas" jämfört med } \\
\text { andra ämne på din } \\
\text { skola. }\end{array}$ & $\begin{array}{l}\text { Hur tror du andra lärare, } \\
\text { elever och skolledningen } \\
\text { ser på den saken? Ex- } \\
\text { empel? } \\
\text { Är det svårare att under- } \\
\text { visa i teknik än i andra } \\
\text { ämnen? (En del lärare } \\
\text { tycker det är svårare att } \\
\text { undervisa i teknik än i } \\
\text { andra ämnen.) } \\
\text { Möjligheten till fortbild- } \\
\text { ning jämfört med andra } \\
\text { ämnen? } \\
\text { Budget? }\end{array}$ \\
\hline $\begin{array}{l}\text { Hur teknikundervis- } \\
\text { ningen bedrivs }\end{array}$ & $\begin{array}{l}\text { Beskriv förutsätt- } \\
\text { ningarna för ämnet } \\
\text { på din skola } \\
\text { Hur tror du att ti- } \\
\text { mantalet och hur } \\
\text { ämnet organiseras på } \\
\text { skolan påverkar din } \\
\text { undervisning? }\end{array}$ & $\begin{array}{l}\text { Eget ämne/integrerat } \\
\text { (med vad?) } \\
\text { Samarbetar du med } \\
\text { andra ämnen? Vilka? } \\
\text { Varför just dessa äm- } \\
\text { nen? } \\
\text { Lokal plan för tek- } \\
\text { nikämnet? } \\
\text { Fastställt timantal? } \\
\text { Hur uppdelat? Årskur- } \\
\text { ser? } \\
\text { Vilken sal har du teknik- } \\
\text { undervisning i? Tycker } \\
\text { du att man måste ha en } \\
\text { särskild tekniksal? Var- } \\
\text { för/varför inte? }\end{array}$ \\
\hline Innehåll och upplägg & $\begin{array}{l}\text { Hur lägger du upp } \\
\text { din undervisning? }\end{array}$ & $\begin{array}{l}\text { Berätta hur du tanker } \\
\text { när du väljer lektionsin- } \\
\text { nehåll. Vad utgår du } \\
\text { ifrån? } \\
\text { Berätta om ett arbets- } \\
\text { område eller en uppgift } \\
\text { som du tycker fungerar } \\
\text { bra. Hur har du fått } \\
\text { idéer och inspiration till }\end{array}$ \\
\hline
\end{tabular}




\begin{tabular}{|c|c|c|}
\hline & & $\begin{array}{l}\text { detta? } \\
\text { Hur hanterar du områ- } \\
\text { den som du känner dig } \\
\text { mindre säker på? } \\
\text { Grupparbeten? Projekt- } \\
\text { arbeten? Handledning? } \\
\text { Är du aktiv/passiv? } \\
\text { Problemlösning? } \\
\text { Elevers frågor? }\end{array}$ \\
\hline Kursplanen i fokus & $\begin{array}{l}\text { Hur använder du } \\
\text { kursplanen för teknik } \\
\text { i din undervisning? }\end{array}$ & $\begin{array}{l}\text { Hur avgör du på vilken } \\
\text { nivå din undervisning } \\
\text { ska ligga? } \\
\text { Vad utgår du ifrån? }\end{array}$ \\
\hline $\begin{array}{l}\text { Eget intresse, egen } \\
\text { säkerhet, egen kun- } \\
\text { skap }\end{array}$ & $\begin{array}{l}\text { Hur säker känner du } \\
\text { dig på att undervisa i } \\
\text { teknik jämfört med } \\
\text { andra ämnen? } \\
\text { Tycker du att du har } \\
\text { den utbildning } \\
\text { och/eller kunskap } \\
\text { som behövs för att } \\
\text { undervisa i teknik? } \\
\text { Skulle du beskriva } \\
\text { dig själv som teknik- } \\
\text { intresserad? }\end{array}$ & $\begin{array}{l}\text { Vad får dig att känna dig } \\
\text { säker på ett ämne? Att } \\
\text { känna trygghet i ämnet? } \\
\text { Berätta om din lärarlegi- } \\
\text { timation. Har något för- } \\
\text { ändrats (i din självbild) } \\
\text { sen du fick den? Berätta! } \\
\text { Vad har du själv för erfa- } \\
\text { renhet och minnen av } \\
\text { teknik från när du själv } \\
\text { gick i skolan? } \\
\text { Hur är det att bedöma } \\
\text { Teknik? Lätt eller svårt? } \\
\text { Jämfört med andra äm- } \\
\text { nen? Exempel på vad } \\
\text { som är svårt? Betygsför- } \\
\text { delningen, hur ser den } \\
\text { oftast ut? Jämfört med } \\
\text { andra? }\end{array}$ \\
\hline $\begin{array}{l}\text { Teknikutbildning } \\
\text { betydelse }\end{array}$ & $\begin{array}{l}\text { Vilken betydelse för } \\
\text { samhället och indivi- } \\
\text { den har teknikutbild- } \\
\text { ning? } \\
\text { Beskriv din syn på } \\
\text { teknik och teknikut- } \\
\text { bildning. Varför ska } \\
\text { vi ha teknik i grund- } \\
\text { skolan? }\end{array}$ & $\begin{array}{l}\text { När och hur har din syn } \\
\text { på teknikutbildning ut- } \\
\text { vecklats? } \\
\text { Vad anser du om att det } \\
\text { är obligatoriskt? Framti- } \\
\text { den för teknikämnet, hur } \\
\text { ser du på den? Vad } \\
\text { kommer ämnet fokusera } \\
\text { på i framtiden? }\end{array}$ \\
\hline
\end{tabular}




\begin{tabular}{|c|c|c|}
\hline & $\begin{array}{l}\text { Vilka färdigheter är } \\
\text { viktiga för eleverna } \\
\text { att kunna i framti- } \\
\text { den? }\end{array}$ & $\begin{array}{l}\text { Var tror du att du har } \\
\text { fått din tekniksyn ifrån? } \\
\text { Du sa tidigare att teknik } \\
\text { är... }\end{array}$ \\
\hline Förutsättningar & $\begin{array}{l}\text { Beskriv förutsätt- } \\
\text { ningarna på skolan. } \\
\text { Är du nöjd med hur } \\
\text { teknikundervisningen } \\
\text { bedrivs totalt sett på } \\
\text { din skola? } \\
\text { Vad behövs för att } \\
\text { förbättra teknikun- } \\
\text { dervisningen på din } \\
\text { skola? } \\
\text { Brinner du eller nå- } \\
\text { gon annan på skolan } \\
\text { för ämnet? Finns det } \\
\text { någon så kallad } \\
\text { eldsjäl? } \\
\text { Får du den utveckl- } \\
\text { ingstid du behöver? }\end{array}$ & $\begin{array}{l}\text { Varför/varför inte? } \\
\text { Vill ledningen utveckla } \\
\text { ämnet? Hur upplever du } \\
\text { att ämnet uppmärk- } \\
\text { sammas och făr stöd } \\
\text { från skolledningen? } \\
\text { HUR får du stöd? Ge } \\
\text { exempel. Mer stöd än } \\
\text { andra ämnen? Ge exem- } \\
\text { pel på hur andra ämnen } \\
\text { uppmärksammas. } \\
\text { Har du tillgång till det } \\
\text { material du behöver? } \\
\text { Tillräcklig budget? Jäm- } \\
\text { fört andra ämnen? }\end{array}$ \\
\hline $\begin{array}{l}\text { Fortbildning/ } \\
\text { kompetensutveckling }\end{array}$ & $\begin{array}{l}\text { Beskriv ett fortbild- } \\
\text { ningstillfälle som du } \\
\text { blivit inspirerad eller } \\
\text { haft nytta av. }\end{array}$ & $\begin{array}{l}\text { Hur har fortbildning } \\
\text { påverkat din undervis- } \\
\text { ning? } \\
\text { Är fortbildning i teknik } \\
\text { viktigt? Varför/varför } \\
\text { inte? } \\
\text { Hur ser du på fortbild- } \\
\text { ning i teknik jämfört } \\
\text { med fortbildning i andra } \\
\text { ämnen? }\end{array}$ \\
\hline Avslut & $\begin{array}{l}\text { Är det något du tyck- } \\
\text { er jag har missat att } \\
\text { fråga om? }\end{array}$ & $\begin{array}{l}\text { Något vi pratat om tidi- } \\
\text { gare som du vill säga } \\
\text { något mer om? }\end{array}$ \\
\hline
\end{tabular}




\section{Bilaga 2: Informationstext, webbenkät}

Hej,

Teknikföretagen och CETIS, Centrum för teknik i skolan, genomför en undersökning om grundskolelärares syn på teknikundervisningen i grundskolan i samarbete med det oberoende undersökningsbolaget Demoskop.

Du har blivit slumpmässigt utvald att delta i denna undersökning som tar ca 8 minuter att besvara. Syftet med undersökningen är att få en tydligare bild av teknikämnets status och hur man arbetar med undervisning i ämnet Teknik på grundskolorna. Resultaten ska primärt användas som en del i en rapport kring ämnet Teknik i skolan.

Självklart är det frivilligt att svara på frågorna, men för vår möjlighet att analysera resultaten är det viktigt att så många som möjligt deltar i undersökningen. Alla dina svar kommer att behandlas helt anonymt och resultaten kommer återges som statistiska variabler.

Eventuella tekniska frågor om enkäten besvaras av Demoskop, peter.rosin@demoskop.se

Kontaktperson för undersökningen hos CETIS är Claes Klasander, telefon 011-36 3307 och på Teknikföretagen Li LjungbergNilsson 08-782 0800 .

Vi tackar på förhand för din medverkan. 


\section{Papers}

The papers associated with this thesis have been removed for copyright reasons. For more details about these see:

http://urn.kb.se/resolve?urn=urn:nbn:se:liu:diva-147766 
Studies in Science and Technology Education

ISSN 1652-5051

FontD

1. Margareta Enghag (2004): MINIPROJECTS AND CONTEXT RICH PROBLEMS Case studies with qualitative analysis of motivation, learner ownership and competence in small group work in physics. (licentiate thesis) Linköping University

2. Carl-Johan Rundgren (2006): Meaning-Making in Molecular Life Science Education upper secondary school students' interpretation of visualizations of proteins. (licentiate thesis) Linköping University

3. Michal Drechsler (2005): Textbooks', teachers', and students' understanding of models used to explain acid-base reactions. ISSN: 1403-8099, ISBN: 91-85335-40-1. (licentiate thesis) Karlstad University

4. Margareta Enghag (2007): Two dimensions of Student Ownership of Learning during Small-Group Work with Miniprojects and context rich Problems in Physics. ISSN: 1651-4238, ISBN: 91-85485-31-4. (Doctoral Dissertation) Mälardalen University

5. Maria Åström (2007): Integrated and Subject-specific. An empirical exploration of Science education in Swedish compulsory schools. (Licentiate thesis) Linköping university

6. Ola Magntorn (2007): Reading Nature: developing ecological literacy through teaching. (Doctoral Dissertation) Linköping University

7. Maria Andreé (2007): Den levda läroplanen. En studie av naturorienterande undervisningspraktiker i grundskolan. ISSN: 1400-478X, HLS Förlag: ISBN 978-917656-632-9 (Doctoral Dissertation, LHS)

8. Mattias Lundin (2007): Students' participation in the realization of school science activities.(Doctoral Dissertation) Linköping University

9. Michal Drechsler (2007): Models in chemistry education. A study of teaching and learning acids and bases in Swedish upper secondary schools ISBN 978-91-7063-1122 (Doctoral Dissertation) Karlstad University

10. Proceedings from FontD Vadstena-meeting, April 2006.

11. Eva Blomdahl (2007): Teknik i skolan. En studie av teknikundervisning för yngre skolbarn. ISSN: 1400-478X, HLS Förlag: ISBN 978-91-7656-635-0 (Doctoral Dissertation, LHS)

12. Iann Lundegård (2007): På väg mot pluralism. Elever i situerade samtal kring hållbar utveckling. ISSN:1400-478X, HLS Förlag: ISBN 978-91-7656-642-8 (Doctoral Dissertation, LHS)

13. Lena Hansson (2007): "Enligt fysiken eller enligt mig själv?" - Gymnasieelever, fysiken och grundantaganden om världen. (Doctoral Dissertation) Linköping University. 
Studies in Science and Technology Education

ISSN 1652-5051

fontD

14. Christel Persson (2008): Sfärernas symfoni i förändring? Lärande i miljö för hållbar utveckling med naturvetenskaplig utgångspunkt. En longitudinell studie i grundskolans tidigare årskurser. (Doctoral Dissertation) Linköping University

15. Eva Davidsson (2008): Different Images of Science - a study of how science is constituted in exhibitions. ISBN: 978-91-977100-1-5 (Doctoral Dissertation) Malmö University

16. Magnus Hultén (2008): Naturens kanon. Formering och förändring av innehållet i folkskolans och grundskolans naturvetenskap 1842-2007. ISBN: 978-91-7155-612-7 (Doctoral Dissertation) Stockholm University

17. Lars-Erik Björklund (2008): Från Novis till Expert: Förtrogenhetskunskap i kognitiv och didaktisk belysning. (Doctoral Dissertation) Linköping University.

18. Anders Jönsson (2008): Educative assessment for/of teacher competency. A study of assessment and learning in the "Interactive examination" for student teachers. ISBN: 978-91-977100-3-9 (Doctoral Dissertation) Malmö University

19. Pernilla Nilsson (2008): Learning to teach and teaching to learn - primary science student teachers' complex journey from learners to teachers. (Doctoral Dissertation) Linköping University

20. Carl-Johan Rundgren (2008): VISUAL THINKING, VISUAL SPEECH - a Semiotic Perspective on Meaning-Making in Molecular Life Science. (Doctoral Dissertation) Linköping University

21. Per Sund (2008): Att urskilja selektiva traditioner i miljöundervisningens socialisationsinnehåll - implikationer för undervisning för hållbar utveckling. ISBN: 978-91-85485-88-8 (Doctoral Dissertation) Mälardalen University

22. Susanne Engström (2008): Fysiken spelar roll! I undervisning om hållbara energisystem - fokus på gymnasiekursen Fysik A. ISBN: 978-91-85485-96-3 (Licentiate thesis) Mälardalen University

23. Britt Jakobsson (2008): Learning science through aesthetic experience in elementary school science. Aesthetic judgement, metaphor and art. ISBN: 978-91-7155-654-7. (Doctoral Dissertation) Stockholm university

24. Gunilla Gunnarsson (2008): Den laborativa klassrumsverksamhetens interaktioner En studie om vilket meningsskapande år 7-elever kan erbjudas i möten med den laborativa verksamhetens instruktioner, artefakter och språk inom elementär ellära, samt om lärares didaktiska handlingsmönster i dessa möten. (Doctoral Dissertation) Linköping University

25. Pernilla Granklint Enochson (2008): Elevernas föreställningar om kroppens organ och kroppens hälsa utifrån ett skolsammanhang. (Licentiate thesis) Linköping University

26. Maria Åström (2008): Defining Integrated Science Education and putting it to test (Doctoral Dissertation) Linköping University

27. Niklas Gericke (2009): Science versus School-science. Multiple models in genetics The depiction of gene function in upper secondary textbooks and its influence on students' understanding. ISBN 978-91-7063-205-1 (Doctoral Dissertation) Karlstad University 
Studies in Science and Technology Education

ISSN 1652-5051

\section{FontD}

28. Per Högström (2009): Laborativt arbete i grundskolans senare år - lärares mål och hur de implementeras. ISBN 978-91-7264-755-8 (Doctoral Dissertation) Umeå University

29. Annette Johnsson (2009): Dialogues on the Net. Power structures in asynchronous discussions in the context of a web based teacher training course. ISBN 978-91977100-9-1 (Doctoral Dissertation) Malmö University

30. Elisabet M. Nilsson (2010): Simulated "real" worlds: Actions mediated through computer game play in science education. ISBN 978-91-86295-02-8 (Doctoral Dissertation) Malmö University

31. Lise-Lotte Österlund (2010): Redox models in chemistry: A depiction of the conceptions held by upper secondary school students of redox reactions. ISBN 97891-7459-053-1 (Doctoral Dissertation) Umeå University

32. Claes Klasander (2010): Talet om tekniska system - förväntningar, traditioner och skolverkligheter. ISBN 978-91-7393-332-2 (Doctoral Dissertation) Linköping University

33. Maria Svensson (2011): Att urskilja tekniska system - didaktiska dimensioner i grundskolan. ISBN 978-91-7393-250-9 (Doctoral Dissertation) Linköping University

34. Nina Christenson (2011): Knowledge, Value and Personal experience - Upper secondary students' use of supporting reasons when arguing socioscientific issues. ISBN 978-91-7063-340-9 (Licentiate thesis) Karlstad University

35. Tor Nilsson (2011): Kemistudenters föreställningar om entalpi och relaterade begrepp. ISBN 978-91-7485-002-4 (Doctoral Dissertation) Mälardalen University

36. Kristina Andersson (2011): Lärare för förändring - att synliggöra och utmana föreställningar om naturvetenskap och genus. ISBN 978-91-7393-222-6 (Doctoral Dissertation) Linköping University

37. Peter Frejd (2011): Mathematical modelling in upper secondary school in Sweden An exploratory study. ISBN: 978-91-7393-223-3 (Licentiate thesis) Linköping University

38. Daniel Dufåker (2011): Spectroscopy studies of few particle effects in pyramidal quantum dots. ISBN 978-91-7393-179-3 (Licentiate thesis) Linköping University

39. Auli Arvola Orlander (2011): Med kroppen som insats: Diskursiva spänningsfält i biologiundervisningen på högstadiet. ISBN 978-91-7447-258-5 (Doctoral Dissertation) Stockholm University

40. Karin Stolpe (2011): Att uppmärksamma det väsentliga. Lärares ämnesdidaktiska förmågor ur ett interaktionskognitivt perspektiv. ISBN 978-91-7393-169-4 (Doctoral Dissertation) Linköping University

41. Anna-Karin Westman (2011) Samtal om begreppskartor - en väg till ökad förståelse. ISBN 978-91-86694-43-2 (Licentiate thesis) Mid Sweden University

42. Susanne Engström (2011) Att vördsamt värdesätta eller tryggt trotsa. Gymnasiefysiken, undervisningstraditioner och fysiklärares olika strategier för energiundervisning. ISBN 978-91-7485-011-6 (Doctoral Dissertation) Mälardalen University

43. Lena Adolfsson (2011) Attityder till naturvetenskap. Förändringar av flickors och pojkars attityder till biologi, fysik och kemi 1995 till 2007. ISBN 978-91-7459-233-7 (Licentiate thesis) Umeå University 
Studies in Science and Technology Education

ISSN 1652-5051

\section{FontD}

44. Anna Lundberg (2011) Proportionalitetsbegreppet i den svenska gymnasiematematiken - en studie om läromedel och nationella prov. ISBN 978-91-7393-132-8 (Licentiate thesis) Linköping University

45. Sanela Mehanovic (2011) The potential and challenges of the use of dynamic software in upper secondary Mathematics. Students' and teachers' work with integrals in GeoGebra based environments. ISBN 978-91-7393-127-4 (Licentiate thesis) Linköping University

46. Semir Becevic (2011) Klassrumsbedömning i matematik på gymnasieskolans nivå. ISBN 978-91-7393-091-8 (Licentiate thesis) Linköping University

47. Veronica Flodin (2011) Epistemisk drift - genbegreppets variationer i några av forskningens och undervisningens texter i biologi. ISBN 978-91-9795-161-6 (Licentiate thesis) Stockholm University

48. Carola Borg (2011) Utbildning för hållbar utveckling ur ett lärarperspektiv Ämnesbundna skillnader i gymnasieskolan. ISBN 978-91-7063-377-5 (Licentiate thesis) Karlstad University

49. Mats Lundström (2011) Decision-making in health issues: Teenagers' use of science and other discourses. ISBN 978-91-86295-15-8 (Doctoral Dissertation) Malmö University

50. Magnus Oscarsson (2012) Viktigt, men inget för mig. Ungdomars identitetsbygge och attityd till naturvetenskap. ISBN: 978-91-7519-988-7 (Doctoral Dissertation) Linköping University

51. Pernilla Granklint Enochson (2012) Om organisation och funktion av människokroppens organsystem - analys av elevsvar från Sverige och Sydafrika. ISBN 978-91-7519-960-3 (Doctoral Dissertation) Linköping University

52. Mari Stadig Degerman (2012) Att hantera cellmetabolismens komplexitet Meningsskapande genom visualisering och metaforer. ISBN 978-01-7519-954-2 (Doctoral Dissertation) Linköping University

53. Anna-Lena Göransson (2012) The Alzheimer A $\beta$ peptide: Identification of Properties Distinctive for Toxic Prefibrillar Species. ISBN 978-91-7519-930-6 (Licentiate thesis) Linköping University

54. Madelen Bodin (2012) Computational problem solving in university physics education - Students' beliefs, knowledge, and motivation. ISBN 978-91-7459-398-3 (Doctoral Dissertation) Umeå University

55. Lena Aretorn (2012) Mathematics in the Swedish Upper Secondary School Electricity Program: A study of teacher knowledge. ISBN 978-91-7459-429-4 (Licentiate thesis) Umeå University

56. Anders Jidesjö (2012) En problematisering av ungdomars intresse för naturvetenskap och teknik i skola och samhälle - Innehåll, medierna och utbildningens funktion. ISBN 978-91-7519-873-6 (Doctoral Dissertation) Linköping University

57. Thomas Lundblad (2012) Simulerad verklighet i gymnasieskolans fysik: en designstudie om en augmented reality simulering med socio-naturvetenskapligt innehåll. ISBN 978-91-7519-854-5 (Licentiate thesis) Linköping University

58. Annie-Maj Johansson (2012) Undersökande arbetssätt i NO-undervisningen i grundskolans tidigare årskurser. ISBN 978-91-7447-552-4 (Doctoral Dissertation) Stockholm University 
Studies in Science and Technology Education

ISSN 1652-5051

fontD

59. Anna Jobér (2012) Social Class in Science Class. ISBN 978-91-86295-31-8 (Doctoral Dissertation) Malmö University

60. Jesper Haglund (2012) Analogical reasoning in science education - connections to semantics and scientific modeling in thermodynamics. ISBN 978-91-7519-773-9

(Doctoral Dissertation) Linköping University

61. Fredrik Jeppsson (2012) Adopting a cognitive semantic approach to understand thermodynamics within science education. ISBN 978-91-7519-765-4 (Doctoral Dissertation) Linköping University

62. Maria Petersson (2012) Lärares beskrivningar av evolution som undervisningsinnehåll i biologi på gymnasiet.ISBN 978-91-7063-453-6 (Doctoral Dissertation) Karlstad University

63. Henrik Carlsson (2012) Undervisningsform, klassrumsnormer och matematiska förmågor. En studie av ett lokalt undervisningsförsök för elever med intresse och fallenhet för matematik. ISBN 978-91-86983-89-5 (Licentiate thesis) Linnaeus University)

64. Anna Bergqvist (2012) Models of Chemical Bonding. Representations Used in School Textbooks and by Teachers and their Relation to Students' Understanding. ISBN 97891-7063-463-5 (Licentiate thesis) Karlstad University

65. Nina Kilbrink (2013) Lära för framtiden: Transfer i teknisk yrkesutbildning. ISBN 978-91-7063-478-9 (Doctoral Dissertation) Karlstad University

66. Caroline Larsson (2013) Experiencing Molecular Processes. The Role of Representations for Students' Conceptual Understanding. ISBN 978-91-7519-607-7 (Doctoral Dissertation) Linköping University

67. Anna-Karin Carstensen (2013) Connect Modelling Learning to Facilitate Linking Models and the Real World through Labwork in Electric Circuit Courses for Engineering Students ISBN 978-91-7519-562-9 (Doctoral Dissertation) Linköping University

68. Konferensproceeding: 10-year Anniversary Meeting with the Scientific Committee

69. Marie Bergholm (2014) Gymnasieelevers kommunikativa strategier i matematikklassrummet. En fallstudie av ett smågruppsarbete om derivata ISBN 97891-7519-306-9 (Licentiate thesis) Linköping University

70. Ingrid Lundh (2014) Undervisa Naturvetenskap genom Inquiry - En studie av två högstadielärare. ISBN 978-91-7519-285-7 (Licentiate thesis) Linköping University

71. Nils Boman (2014) Personality traits in fish - implications for invasion biology ISBN:978-91-7601-097-6 (Licentiate thesis) Umeå University

72. Torodd Lunde (2014) När läroplan och tradition möts - lärarfortbildning och syften med undersökande aktiviteter inom den laborativa NO-undervisningen i grundskolans senare del. ISBN: 978-91-7063-577-9 (Licentiate thesis) Karlstad University

73. Martin Eriksson (2014) Att ta ställning - gymnasieelevers argumentation och beslutsfattande om sociovetenskapliga dilemman. ISBN 978-91-7063-588-5 (Licentiate thesis), Karlstad University

74. Annalena Holm (2014) Mathematics Communication within the Frame of Supplemental Instruction. Identifying Learning Conditions. ISBN 978-91-7623-112-8 (Licentiate thesis) Lund University 
Studies in Science and Technology Education

ISSN 1652-5051

fontD

75. Daniel Olsson (2014) Young people's 'Sustainability Consciousness' - Effects of ESD implementation in Swedish schools. ISBN 978-91-7063-594-6. (Licentiate thesis) Karlstad University

76. Marlene Sjöberg (2014) Möjligheter I kollegiala samtal om NO-undervisning och bedömning. https://gupea.ub.gu.se/handle/2077/24063 (Licentiate thesis) Gothenburg University.

77. Teresa Berglund (2014) Student 'Sustainability Consciousness' and Decision-Making on Sustainability Dilemmas. Investigating effects of implementing education for sustainable development in Swedish upper secondary schools. ISBN 978-91-7063599-1 (Licentiate thesis) Karlstad University

78. Elisabet Mellroth (2014) High achiever! Always a high achiever? A comparison of student achievements on mathematical tests with different aims and goals. ISBN 97891-7063-607-3 (Licentiate thesis) Karlstad University

79. Jenny Green (2014) Elevers användande av formativ återkoppling i matematik. ISBN 978-91-7519-164-5 (Licentiate thesis) Linköping University

80. Klara Kerekes (2014) Undervisning om växande geometriska mönster-en variationsteoretisk studie om hur lärare behandlar ett matematiskt innehåll på mellanstadiet. ISBN: 978-91-7519-135-5 (Licentiate thesis) Linköping University

81. Cecilia Axell (2015) Barnlitteraturens tekniklandskap: en didaktisk vandring från Nils Holgersson till Pettson och Findus. ISBN 978-91-7519-227-7 (Doctoral Dissertation) Linköping University.

82. Jan Forsgren (2015) Synthesis and characterization of catalysts for hydrogen production from water ISBN 978-91-7601-206-2.(Licentiate thesis) Umeå University

83. Maria Eriksson (2015) Att kommunicera naturvetenskap i nationella prov: En studie med andraspråksperspektiv. ISBN 978-91-7519-138-6 (Licentiate thesis) Linköping University

84. Tomas Jemsson (2015) Time correlated single photon spectroscopy on pyramidal quantum dots. ISBN 978-91-7519-143-0 (Licentiate thesis) Linköping University

85. Helen Hasslöf (2015) The Challenge of Education for Sustainable Development. Qualification, social change and the political ISBN: 978-91-7519-127-0 (Doctoral Dissertation) Linköping University.

86. Johan Sidenvall (2015) Att lära sig resonera - Om elevers möjligheter att lära sig resonera matematiskt. ISBN 978-91-7519-100-3 (Licentiate thesis) Linköping University.

87. Jonas Jäder (2015) Elevers möjligheter till lärande av matematiska resonemang. ISBN 978-91-7519-099-0 (Licentiate thesis) Linköping University.

88. Laurence Russell (2015) Exploring systematic lesson variation -a teaching method in mathematics. ISBN 978-91-7519-041-9 (Licentiate thesis) Linköping University.

89. Roger Andersson (2015). Ett lysande experiment. En studie av lärandeprogressionen vid lärande med datorstöd i optik. ISBN 978-91-7485-215-8 (Licentiate thesis)

Mälardalen University. 
Studies in Science and Technology Education

ISSN 1652-5051

fontD

90. Therese Granekull (2015). Kamratbedömning i naturvetenskap på mellanstadiet formativ återkoppling genom gruppsamtal. ISBN: 978-91-86295-74-5 (Licentiate thesis) Malmö högskola.

91. Yukiko Asami-Johansson (2015) Designing Mathematics Lessons Using Japanese Problem Solving Oriented Lesson Structure. A Swedish Case Study. ISBN. 978-917685-990-2 (Licentiate thesis) Linköping University.

92. Katarina Ottander (2015). Gymnasieelevers diskussioner utifrån hållbar utveckling. Meningsskapande, naturkunskapande, demokratiskapande. ISBN 978-91-7601-322-9 (Doctoral Dissertation) Umeå University

93. Lena Heikka (2015) Matematiklärares målkommunikation - En jämförelse av elevernas uppfattningar, lärarens beskrivningar och den realiserade undervisningen. ISBN: 978-91-7583-446-7 (Licentiate thesis) Luleå University of Technology.

94. Anette Pripp (2016) Välja teknik? Ungdomars röster om valet till gymnasiets teknikprogram. ISBN 978-91-7685-775-5 (Licentiate thesis) Linköping University.

95. Annika Pettersson (2016) Grafisk och algebraisk representation: Gymnasieelevers förståelse av linjära funktioner. ISBN 978-91-7063-705-6 (Licentiate thesis) Karlstad University.

96. Erika Boström (2017) Formativ bedömning: En enkel match eller en svår utmaning? Effekter av en kompetensutvecklingssatsning på lärarnas praktik och på elevernas prestationer i matematik. ISBN 978-91-7601-706-7 (Doctoral Dissertation) Umeå University.

97. Gustav Bohlin (2017) Evolving germs - Antibiotic resistance and natural selection in education and public communication. ISBN: 978-91-7685-489-1 (Doctoral Dissertation) Linköping University.

98. Daniel Åkerblom (2018) Meningsfullhet i lärandet - hur kan autenticitet förändra undervisningspraktiken? ISBN: 978-91-88761-19-4 (Licentiate thesis) Linnaeus University.

99. Charlotta Nordlöf (2018) Tekniklärares attityder till teknikämnet och teknikundervisningen. ISBN 978-91-7685-328-3 (Licentiate thesis) Linköping University. 